\title{
OLASZ Lajos ${ }^{*}$ \\ A csendőrség szerepe a polgári repülésben a két a világháború között
}

(The role of the gendarmerie in civil aviation between the two world wars.)

\begin{abstract}
Absztrakt
A trianoni békediktátum — számos megalázó és korlátozó intézkedése mellett — szinte teljesen felszámolta a magyar repülést, különösen annak katonai vállfaját. Ezt a helyzetet a magyar állam — támaszkodva a változó nemzetközi erőviszonyokra csak fokozatosan, több évtized alatt tudta felszámolni. A magyar repülés fejlesztésében általában, különösen pedig a katonai repülés rejtésében a Magyar Királyi Csendőrség jelentős szerepet kapott, mely feladatát a testület kiválóan teljesítette. A két világháború közötti időszakban a Magyar Királyi Csendőrség szervezetében alakultak ki a magyar légirendészet kezdeti formái, melyre a koronát a háború miatt rövid életü légicsendőrség felállítása helyezte.
\end{abstract}

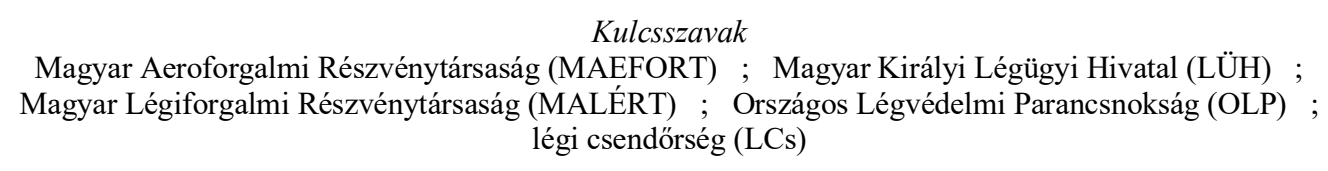

Kulcsszavak

Magyar Aeroforgalmi Részvénytársaság (MAEFORT) ; Magyar Királyi Légügyi Hivatal (LÜH) ; Magyar Légiforgalmi Részvénytársaság (MALÉRT) ; Országos Légvédelmi Parancsnokság (OLP) ; légi csendőrség (LCs)

Abstract

The Trianon peace dictatorship, in addition to a number of humiliating and restrictive measures, almost completely abolished Hungarian aviation, especially its military shoulder race. Relying on the changing international power relations, the Hungarian state could only eliminate this situation gradually, over several decades. The Royal Hungarian Gendarmerie played a significant role in the development of Hungarian aviation in general, and in the concealment of military aviation in particular, and the body performed its task excellently. In the period between the two world wars, the initial forms of the Hungarian Air Force developed in the organization of the Hungarian Royal Gendarmerie, on which the crown was placed by the establishment of a short-lived air gendarmerie due to the war.

Key words:

Hungarian Air Transport Company (MAEFORT) ; Royal Hungarian Aviation Authority (LÜH) ;

Hungarian Aviation Company (MALÉRT) ; National Air Defense Command (OLP) ; air gendarmerie (LCs)

*

Open Researcher and Contributor ID = Nyílt Kutató és Közremüködő Azonosító (ORCID) : https://orcid.org/0000-0002-4463-3251

Institutional attachements = Szerző intézményi kötődései :

- University of Szeged = Szegedi Tudományegyetem

- Hungarian Military Science Society = Magyar Hadtudományi Társaság

-Hungarian Historical Society = Magyar Történelmi Társulat

Date of registry $=$ Regisztrálás dátuma : 2020. VI. 10 .

@: olasz@jgypk.szte.hu

DOI : 10.31627/RTF.XXX.2020.59-60N.115-140P

Date of acceptance $=$ elfogadás dátuma $: 2019$. VII. 9. 
A z 1919-ben nyilvánosságra kerülő előzetes békefeltételek világossá tették, hogy az antant hatalmak megtiltják a vesztes államok számára a légierő tartását, de a polgári repülést is jelentős mértékben korlátozni kívánják. Ennek ismeretében a magyar hadügyi tárca légügyekkel foglalkozó 37. osztályát formálisan felszámolták, és helyette 1920. I. 1-jén felállították a Magyar Királyi Kereskedelemügyi Minisztérium (KEM) II. „légiforgalmi” osztályát. Ez töltötte be a légügyi hatóság szerepét, szabályozta a légi közlekedést, ellenörzése alatt állt a négy közforgalmi célra használt repülötér, valamint a légügyi szervezetek számára adatokat szolgáltató 15 meteorológiai állomás. (I.sz. melléklet) Az új szervezet a polgári repülés, légügyi irányítás és légi rendészet megszervezése mellett, titokban a katonai repülés vezető szervezete is volt, személyzete a 37. osztály korábbi személyi állományából került ki, az irányítását pedig PETRÓCZY István alezredes, új hivatalos titulusával: légügyi aligazgató (1920. I. 29-tôl légügyi igazgató) látta el. ${ }^{1}$

A polgári aviatika fejlesztése (és a katonai repülés rejtett fenntartása) érdekében 1920. II. 11-én légiforgalmi vállalatot hoztak létre. A Magyar Aeroforgalmi Rt. (MAEFORT), hivatalosan magáncég volt, de jelentős állami támogatást kapott, és kormányzati ellenőrzés alatt müködött. A vállalat biztosította a KEM irányítása alatt álló négy közforgalmi célra használt repülőtér napi müködését, szakszemélyzettel való ellátását (Budapest, Szeged, Szombathely, Miskolc), emellett repülőjavító mühelyt, anyagraktárt tartott fenn. A cég keretében pilótaképzés folyt. A forgalmi repülések és a kiképzés lehetővé tették viszonylag nagyobb hajózó állomány, irányító és műszaki személyzet (korábbi katona) alkalmazását, gyakorlatban tartását. A MAEFORT 1920. X. 11-én a 22 (katonai célra is alkalmas) „forgalmi" géppel, 20 iskolagéppel és 60 javításra váró repülőgéppel rendelkezett, ezen kívül további 51 gép gyártását rendelte meg. Személyzetéhez 689 tisztviselő és polgári alkalmazott (valójában 130 tiszt, 58 altiszt és 501 fö legénység) tartozott. ${ }^{2}$

A budapesti bázis mellett Szegeden, Szombathelyen és Miskolcon is MAEFORT kirendeltség létesült, és jelen voltak a másik magyar repülő szervezet a Magyar Aero Szövetség (MAeSZ) helyi csoportjai is. A négy repülőtéren postaszállitás, pilótaképzés, sportrepülés folyt három vidéki repülötéren is pilótaképzés kezdődött, Aszódon pedig repülőgép-szerelő tanfolyamot szerveztek. Az első rendszeres postajárat 1920. V. 12én indult Budapest és Szeged között. A reptereken gyakran megfordultak a győztes nagyhatalmak repülögépjei is, mert a békeszerződés értelmében a Szövetséges és Társult Hatalmak repülögépjei Magyarország légterében szabadon közlekedhettek, és használhatták a repülőtéri létesítményeket. ${ }^{3}$

A Nagykövetek Tanácsa messze túllépve a békediktátum hivatalos elöírásait 1921. V. 5-én megtiltotta a legyőzött államoknak motoros repülőgépek gyártását vagy külföldi beszerzését („londoni ultimátum”). Ez nemcsak katonai, hanem polgári gépekre is vonatkozott, és hosszabb távon is visszavetette a magyar aviatika fejlődését. Az 1920. VI. 4-én aláírt és 1921. VII. 26-án érvénybe lépő békediktátum fél évre (1922. I. 26-ig) teljes repülési tilalmat rendelt el a magyar gépek számára. A Szövetségközi Katonai Ellenőrző Bizottság (SZKEB) közegei szigorú ellenőrzés alá vonták a polgári légügyek területét is, és vizsgálni kezdték a KEM II. osztálya tevékenységét. Ezért a kereskedelemügyi tárcánál átszervezéseket hajtottak végre, és a légügyi hatósági, légi közlekedési és légi rendészeti témák kezelését 1921. VIII. 1jén átvette a minisztérium újonnan felállított XI. osztálya. Ez azonban polgári feladatai mellett ugyanúgy katonai feladatokat, a légierő megmaradt törzsének, állományának, gépjeinek rejtését végezte, mint az elődje, csak a honvédelmi tárca Várbeli, Bécsi kapu téri épületéből, a KEM Hunyadi János utca 1. szám alatti székházába költözött át. ${ }^{4}$

Közben a SZKEB Légügyi Ellenőrző Bizottságának tagjai járták az országot, és minden megtalált repülőgépet szétromboltattak. Az év végéig elszállítottak vagy megsemmisítettek 119 repülógépet, 77 motort és nagyszámú müszaki felszerelést, speciális szerszámgépet, leromboltak hét hangárt és számos reptéri építményt. A többi repülötéri létesítményt csak úgy sikerült megmenteni, hogy a magyar kormány 1921. XI. 7-én aláírt egy előnytelen szerződést, amelyben a hangárok és egyéb kiszolgáló építmények használati jogát a repülési tilalom lejártáig átadta a győztes hatalmaknak. ${ }^{5}$

A repülési tilalom és a repülőgép-rombolás mellett a SZKEB a MAEFORT felszámolását is követelte, arra hivatkozva, hogy az rejtett katonai szervezet. Így a vállalat 1921. XII. 8-án beszüntette a müködését. További, a békediktátumban nem szereplő korlátozást jelentett a magyar polgári repülés megalapozása tekintetében, hogy az 1922. I. 26-án lejáró repülési és repülóépítési tilalmat a Nagykövetek Tanácsa minden előzetes indoklás nélkül, az év végéig meghosszabbította. Ez már nem elsősorban a katonai repülés felszámolását szolgálta, hanem gazdasági előnyhöz igyekezett juttatni nyugati érdekeltségeket, amelyek a repülőgépgyártás, illetve a kereskedelem és szállítás területén közép-európai piacokat, koncessziókat igyekeztek szerezni. ${ }^{6}$

\section{A reptérgondnokságok és csendőrkkülönítmények}

A MAEFORT feloszlatását és a repülési tilalom meghosszabbítását követően 1922 elején a párizsi székhelyü Francia-Román Légitársaság nemzetközi útvonalengedélyt kért Párizsból Prága érintésével Budapestig, majd onnan Belgrádon, illetve Bukaresten át Konstantinápolyig. A Francia-Román 
Légitársaság 1922. IV. 29-től megkapta a szükséges engedélyeket és 1922. VII. 1-től rendszeres légi járatot indított Párizs és Budapest közöttt. ${ }^{7}$

A nemzetközi légi forgalom megindításához azonban a gépek kiszolgálását biztosító reptéri szervezetre volt szükség, amelyet a MAEFORT látott el. Ezért 1922. III. 1-jén öt magyarországi repülőtéren (Mátyásföld, Szeged, Szombathely, Miskolc, Székesfehérvár) úgynevezett reptérgondnokságokat állítottak fel. Ezek feladata volt, a légi forgalmat segítő létesítmények üzemeltetése, a gépek fogadása és indítása, a szükséges müszaki feladatok ellátása, a rádiószolgálat fenntartása, az útlevél és vámügyek intézése, valamint a nemzetközi légiközlekedési szabályok betartatása, a légi rendészeti feladatok ellátása is. A reptérgondnokságok egyelöre egy éves ideiglenes megbízatást kaptak, mert várható volt, hogy a hazai repülést sújtó tilalmakat 1922 végére legalább részben feloldják. A gondnokságok szakállományát a korábbi MEAFORT személyzet alkotta, a repülőterek őrzését viszont a területileg illetékes csendőr alakulat látta el tartós vezényléssel, illetve járörfeladat keretében. ${ }^{8}$

A Magyarországgal szembeni szankciók fokozatos feloldása keretében 1922. IX. 14-én megszünt a már több mint egy éve tartó repülési tilalom. A magyar kormány korábbi kezdeményezése során az országot 1922. IX. 18-án felvették a Nemzetek Szövetségébe. 1922. XI. 17-én megszünt az ország közvetlen légügyi ellenőrzése, és feloldották a repülőgépgyártásra, illetve behozatalra vonatkozó teljes tilalmat. Ezt azonban az úgynevezett 9-es szabály váltotta fel. A katonai repülést továbbra is tiltották a vesztes államok számára, és csak olyan polgári repülőgépek tartását engedélyezték, melyek müszaki és teljesítményi mutatói kilenc területen (sebesség, repülési magasság, repülési távolság, hasznos terhelés stb.) messze elmaradtak a katonai repülőgépek mögött. Ez a korlátozás a győztes államok polgári gépeire természetesen nem vonatkozott.'

Fennálltak egyéb, a polgári repülést korlátozó rendelkezések is, annak ellenére, hogy ezek tételesen nem szerepeltek a békediktátumban. A SZKEB ragaszkodott a repülőgépgyártás, a pilótaképzés, a repülő egyesületek, a repülőtulajdonosok nyilvántartásához és az adatok átadásához. Tiltották a sportrepülés központi anyagi támogatását, illetve a honvédség és a rendvédelmi erők tagjai nem vehettek részt a sportrepülésben. A fegyveres testületek tagjai közül évente csak 12 fö kaphatott pilótaképzést. Légi rendőrséget vagy csendőrséget a legyőzött államok nem tarthattak, bár erre a légi rendészet, a csempészés vagy az illegális határátlépés megakadályozása terén rendkívül nagy szükség lett volna. ${ }^{10}$

A korábbi korlátozások részleges feloldása ugyanakkor lehetővé tette magyar légi közlekedési vállalatok létesítését. A Magyar Légiforgalmi Rt. (MLRT) már 1922. V. 2-án megszerezte a szükséges engedélyokiratot, a repülési tilalom miatt azonban csak 1922. XI. 19-én tudott megalakulni, és járatot hirdetni a Bécs-Budapest-Belgrád vonalon. Az Aeroexpress 1922. XI. 22-én szerezte meg a szükséges müködési engedélyt, és ennek birtokában 1923. I. 10-től üzemelt, Budapest-Bécs, Prága-Budapest-Zágráb és Budapest-Bukarest járatokat indítva. ${ }^{11}$

Magyarország légügyi szuverenitása 1923. I. 1-jén helyreállt. Ezért a légi felségjog érvényesítése érdekében a magyar légtérben való közlekedés szabályairól külön kormányrendeletet adtak ki. A Minisztertanács által december 14-én elfogadott rendelet december 19-én lépett érvénybe. Ehhez a felhatalmazást az 1922ben alkotott törvény biztosította, amely kimondta, hogy amíg a törvényhozás külön jogszabályt nem alkot, addig a légi közlekedéssel kapcsolatos ügyeket a kormány rendeleti úton szabályozza. ${ }^{12}$

A rendelet leszögezte, hogy a magyar állam felségjoga az ország területe feletti légtérre is kiterjed. Magyarország elismeri a légi közlekedés szabadságát, e téren azonban, más országokhoz hasonlóan a szükséges mértékben szabályozást, korlátozást érvényesít. A légi jármüvek tartása bejelentés-köteles, a tulajdonba kerülést követő öt napon belül jelenteni kellett a rendőrség budapesti, illetve vidéki kerületi főkapitányságain. A légteret csak regisztrált, lajstromjellel ellátott, az alkalmasságot igazoló müszaki és szakszolgálati engedélyekkel rendelkező légi jármü használhatta. A rendelet részletesen szabályozta a repülőtér létesítésének és légi forgalmi vállalat alapításának feltételeit. ${ }^{13}$

A szabályok kimondták, hogy fel- és leszállni csak kijelölt repülőtéren lehetett, külföldi gépeknek pedig csak vámreptéren. Ettől eltérni csak a KEM előzetes írásbeli engedélye esetén lehetett. Repülőtéren kívüli kényszerleszállás esetén a személyzetnek jelentkeznie kellett a legközelebbi rendfenntartó közegnél, illetve továbbrepülés esetén tájékoztatni kellett az eseményröl annak a reptérnek a személyzetét, ahová a gép megérkezett. Minden repülőgépen ott kellett lenni a szükséges dokumentumoknak (légi alkalmasság igazolás, lajstromkivonat, a személyzet szakszolgálati engedélye, személyzeti és utaslista, az árujegyzék, légjárómü napló). Fegyver, lőszer, robbanóanyag, vegyi harcanyag, illetve fényképező, postagalamb és rádiókészülék csak a légügyi hatóság (KEM XI. szakosztály) külön engedélyével volt szállítható. Repülőbemutatók, repülő versenyek rendezéséhez a belügyi tárca és a légügyi hatóság hozzájárulása kellett. Az ország területén tilalmi övezeteket jelöltek ki, elsósorban katonai szempontból fontos körzeteket, amelyek fölé nem volt szabad berepülni. Minden légi jármü köteles volt engedelmeskedni, ha nemzetközi szokásokhoz hasonló fényjelzésekkel vagy egyéb módon a magyar hatóságok leszállásra szólították fel. ${ }^{14}$ (II.sz. melléklet)

A külföldi légi jármü csak a magyar légügyi hatóság (KEM XI. szakosztály) 30 napra érvényes elözetes átrepülési engedélyével léphetett be a magyar légtérbe. A légügyi szervek minden átrepülésről tájékoztatták a Magyar Királyi Belügyminisztériumot (BM) is. Külföldi katonai gépek csak a HM külön engedélyével repülhettek át a magyar légtéren. A jogosulatlanul közlekedő légi jármüveket a magyar 
hatóságok leszállásra szólíthatták fel. Nappal 10 másodpercenként fellőtt, fehér füstöt árasztó, éjszaka zöld fényt árasztó lövedékekkel jelezték ezt a gépeknek. A leszállás megtagadása esetén az illetékes szervek elvben kényszerítő eszközöket is igénybe vehettek, repülögépekkel felszerelt rendvédelmi erők hiányában azonban nemigen voltak hatékony eszközeik. A légteret, vagy a légi közlekedési szabályokat megsértő repülőgépekre a földről csak a HM külön engedélye alapján nyithattak tüzet. ${ }^{15}$

A rendelet megállapította, hogy a légi közlekedés feletti felügyeletet a KEM gyakorolja, rendészeti kérdésekben a belügyi tárcával egyetértően. A trianoni tiltó rendelkezések, és a szükséges anyagiak hiánya miatt önálló légiforgalmi rendőrség (csendőrség) egyelőre nem kerül felállításra, ezért a rendészeti feladatokat a rendőrség, a csendőrség és a vámőrség kijelölt szervezeti egységei látták el. Nem büncselekménynek minősülő szabályszegés esetén a kiszabható büntetés $2000 \mathrm{~K}$ bírság vagy 15 napi elzárás volt. Kihágás esetén a rendőrség vagy a helyileg illetékes közigazgatási hatóság járt el. A büntetés vitatása esetén az érintett a légügyi hatósághoz fordulhatott jogorvoslatért. ${ }^{16}$

A gyorsan bővülö légi forgalom felügyeletére, illetve az illegális légtérhasználat lehetőség szerinti megakadályozására, élve a légi szuverenitásból eredő jogokkal, 1923. II. 1-jén légi ellenőrző szolgálatot szerveztek. Ez a feladat döntően a honvédségre és a rendvédelmi szervezetekre hárult. A katonai helyörségek, a pályaudvar- és hídőrségek, a rendőrség, a csendőrség, folyamőrség és a vámőrség alakulatai, továbbá felállított őrségei vagy járőrei kötelesek voltak folyamatosan figyelni a légteret. Minden átrepülő külföldi gépről feljegyzést készítettek, melyeket havi összesítésben felterjesztettek saját kerületi parancsnokságuk, és azon keresztül a légügyi hatóság számára. ${ }^{17}$

A korábbi ideiglenes szabályozás után 1923. III. 1-től állandó reptérgondnokságokat szerveztek. Az országot a hét vegyesdandár (egyben csendőr kerület, vámőr kerület stb.) területi illetékességének megfelelően hét reptérgondnoksági kerületre osztották, mindegyikben egy-egy repülőtérrel. Egyelőre öt közforgalmi célokat is szolgáló repülőtéren (Mátyásföld, Szombathely, Székesfehérvár, Miskolc, Szeged) csendőr különítményeket állítottak fel, melyek a gondnokságok tevékenységét irányították. Kaposváron és Nyíregyházán nem volt állandó szolgálat, a légügyi feladatokat egy-egy kijelölt előadó látta el. ${ }^{18}$

A csendőr különítmények a Vezényelt csendőregyének osztaga (VECSOG) alárendeltségébe tartoztak, amely közvetlenül a csendőrség felügyelője irányítása alatt állt. A különítmények személyi állományát azonban döntően, a korábban a légierőnél szolgáló katonák alkották, rejtett státuszban. Mivel a csendőrség 1921. VI. 3-tól hivatalosan a belügyi tárca alá tartozott, a reptéri csendőrség állománya nem számított bele a trianoni rendelkezések által szigorúan korlátozott honvédségi létszámkeretekbe. A reptéri különítmények a csendőrség szolgálati szabályai szerint, csendőr egyenruhában látták el a szolgálatot, és tevékenységüket a belügyi tárca költségvetéséböl finanszírozták, valójában azonban a légügyi hatóságon keresztül a HM katonai csoportfönöke rendelkezett felettük. ${ }^{19}$

A reptérgondnokságok, és ezek keretében a repülőtéri csendőr különítmények feladatkörét a KEM 1923. évi rendelete szabályozta. ${ }^{20}$ A reptérgondnokságok légügyi igazgatási, légiforgalmi irányítási és légi rendészeti feladatokat láttak el. Az illetékességük alá tartozó terület központi repülöterén a csendőrkülönítmény parancsnoka úgynevezett reptérrendet dolgozott ki és vezetett be. Ez tartalmazta a légi jármüvek kötelező magatartásszabályait a földön és a levegőben, az érkező és távozó repülö személyzet eligazítására vonatkozó tudnivalókat, a repülőtér biztonságát és védelmét szolgáló nappali és éjszakai őrszolgálat megszervezését. A rendtartás kitért a rádióforgalom müködésére, a karbantartás elvégzésére, a repülőtér helyiségei tisztántartására, a reptéri étterem (étkezde, kantin) nyitvatartására, illetve a helyi telefon használatára is. ${ }^{21}$

Külön fejezetet képezett a rendtartásban a repülőtér tüzvédelmének szabályozása, hogy melyik létesítményben (parancsnokság, csarnok, mühely, hangár) milyen tüzoltó felszerelésről, oltóanyagról (oltókészülék, fecskendő, homok, víztartály, vegyi anyagok) kellett gondoskodni, hogy ki kezeli a tüzvédelmi eszközöket. Tüzveszély esetén a repülőtér teljes személyzete az ügyeletes csendőrtisztnek, altisztnek volt alárendelve. A reptéri csendőrség időközönként tüzriadó gyakorlatot rendelt el. ${ }^{22}$

A közforgalmi repülőterek napi tevékenységét a repülőtér-vezető (a reptéri csendőr különítmény parancsnoka) irányította. Az ügyeleti szolgálat, melyet csendőrök láttak el, gondoskodott a folyamatos üzem biztosításáról, a szükséges szervezési és adminisztratív feladatok ellátásáról, a fel- és leszállások engedélyezéséről, repülőgépek indításáról és fogadásáról, valamint a rend fenntartásáról. Ezen kívül, a repülőtereken szerelő szolgálat müködött, folyamatosan rendelkezésre állt legalább egy repülőgép ellátásához szükséges müszaki személyzet. A rádió-távírász szolgálat feladata kezdetben a szomszédos repülőterekkel való kapcsolattartás, a forgalmi információk és az időjárás-jelentések továbbítása, fogadása volt. A levegőben lévő gépekkel való kapcsolattartás csak az 1930-as években terjedt el. A rádiószolgálatot a Magyar Királyi Posta személyzete látta el, de a távírász is a repülőtér-vezető irányítása alá tartozott. A repülötereken egészségügyi szolgálatot is kellett biztosítani, amit a nemzetközi forgalmat bonyolító Mátyásföldön orvos, máshol elsősegélynyújtásra szakmai képzést kapott személy látott el. ${ }^{23}$

A reptérgondnokságok hatáskörébe tartozott az adott kerületben a repülötéren kívüli fel- és leszállások engedélyezése, különböző repülő rendezvények, bemutatók, versenyek felügyelete. Alapelvként az szolgált, hogy az adott település közigazgatási hatóságának és az érintett telek tulajdonosának engedélyére volt szükség. A fel- és leszállómező legalább egy 300 m hosszú tömör talajú terület kellett, hogy legyen, amely körül 500 méteres körzetben nem volt olyan természetes akadály vagy építmény (gyárkémény, 
telefonvezeték), ami a repülést veszélyeztethette volna. Minden vonatkozó dokumentumot, hozzájárulást az esemény előtt 48 órával be kellett mutatni az engedélyező légügyi hatóságnak (reptérgondnokságnak). Magának a rendezvénynek a biztosítását nem a repülőtéri csendőrség végezte, hanem a helyi közigazgatás intézkedése nyomán az adott településen illetékes rendőrkapitányság vagy csendőr őrs. ${ }^{24}$

A polgári repülés hírközlési infrastruktúráját a Magyar Királyi Posta biztosította. Központi Távíróhivatal Rádió Üzemközpontja kirendeltséget létesített a Mátyásföldi repülőtéren. A rádióadót Csepelen állították fel, ez továbbította hazai és külföldi repülőterekre az üzeneteket, amit a posta távírászai Mátyásföldön billentyüztek be. A vevőkészülék a központi vámreptéren müködött. Az 1920-as években mindez még csak napi 20-30 üzenetváltást jelentett. A rádiószolgálatot 1933. II. 28-ig látta el a Magyar Királyi Posta, utána a Magyar Királyi Légügyi Hivatal (LÜH) vette át, vagyis a gyakorlatban a honvédség híradósai végezték. A légiközlekedés meteorológiai információinak bővítésére, Szegeden, még 1922 decemberében Időjárás Kutató Állomást létesítettek. Ez az intézmény ugyan rejtett katonai egység volt, a pilótaképzést és a vadászrepülők gyakorlatban tartását szolgálta, az I. világháború egyik ismert repülője HÁRY László vezetésével (később ő lett a légierő parancsnoka). A kiképző keret tisztjei és altisztjei a helyi repülőtéri csendőrkülönítmény állományában szolgáltak. A katonai feladatok mellett azonban a szegedi állomás valóban vizsgálta a légköri folyamatokat és széleskörü információkat szolgáltatott a polgári repülésnek, amelyről az állomás főmeteorológusa HILLE Alfréd gondoskodott, aki a föszervezője volt az országos a repülő-meteorológiai szolgálatnak. ${ }^{25}$

A reptérgondnokságok felállítását követően a KEM sorra adta ki a légiközlekedés egy-egy részterületét érintő rendeleteit. 1933. IV. 14-én jelent meg a „tilalmi övezeteket” tartalmazó szabályozás, ${ }^{\mathbf{2 6}}$ amely térség felett a hazai vagy külföldi gépeknek tilos volt átrepülni. Ezekről minden magyar repülöszervezet részletes tájékoztatást kapott, és ismertetőt küldtek minden külföldi személynek is, aki átrepülési engedélyt kért az ország felett. ${ }^{27}$

1923. IV. 26-án új szabályozás lépett a nagyhatalmak által korábban az országra kényszerített, de időközben lejárt repülötér- és hangár-használati szerződés helyébe. Magyarország visszakapta a teljes rendelkezési jogot reptéri létesítményei felett. Cserébe a magyar kormány vállalta, hogy nem használja a létesítményeket katonai célokra, illetve biztosítja a nemzetközi légi forgalom zavartalan lebonyolítását. Központi vámrepteret és szükségleszálló helyeket üzemeltet a megfelelő berendezésekkel és szolgálatokkal, és a hangárokban helyet biztosít a Szövetséges és Társult Hatalmak repülögépjeinek. Ezt követte a magyarországi légi jármüveken alkalmazott jelzéseket szabályozó rendelet, mely meghatározta, hogy minden polgári repülő szerkezet öt elemből álló betűsort viseljen. Ebből az első két elem „H-M” a nemzeti hovatartozást jelölte a nemzetközi repülőszervezet által kiosztott jelrendszernek megfelelően. A következő három betủ pedig (pl. AAA) a gép egyéni lajstromjele volt. Együtt alkották a repülőgép rádió hívókódját (H-MAAA).

1924-re megélénkült a légi forgalom Magyarországon, ami újabb rendelkezések kiadását, illetve a korábbi ideiglenes jellegü szabályozások módosítását vonta maga után. Az új intézkedések több ponton bővítették a reptérgondnokságok, és az ezek feladatait ellátó reptéri csendőr különítmények kötelezettségeit és egyben hatáskörét. A reptéri csendőrség számára fokozott terheket jelentett a légügyi hatósági, a légi közlekedési és a légi rendészeti feladatok egyszerre történő ellátása. ${ }^{2}$

Az új helyzetben szükségessé vált a légiközlekedésre vonatkozó szabályozás módosítása. ${ }^{30} 1924$. II. 22-én új kormányrendelet született, amely több ponton kiegészítette a korábbi jogszabályt. Ezt egy sor szakminiszteri rendelkezés követte, melyek az egyes részterületeken vezettek be korszerúbb elöírásokat. 1924. III. 8-án új rendelet jelent meg a repülöterek létesítésére és müködtetésére vonatkozóan, amely érintette a reptérgondnokságok hatáskörét is. Új repülötér kialakítása előtt a reptérgondnokság feladata volt a kiválasztott helyszín megvizsgálása és jóváhagyása. A reptér üzembe helyezése elött egy újabb szemle következett, amikor a légügyi hatóság (a reptérgondnokság) megvizsgálta, hogy a létesítmény alkalmas-e a fel- és leszállásokra, megvannak-e a szükséges berendezések, felszerelések (szélzsák, leszállási jel, önműködő szélirányjelző, piros, fehér, zöld színű rakéták), illetve megszervezték-e az állandó vagy ideiglenes (az esetenként repülő eseményeket biztosító) reptéri szolgálatot. ${ }^{31}$

A rendelet harmadik része a repülőterek igazgatásával foglalkozott. Minden felszállóhely a területileg illetékes reptérgondnokság hatáskörébe tartozott, amely félévenként szemlét tartott a magáncélú (vállalati) és ideiglenesen használt reptereken is. A repülőtéri szolgálat tagjai feladatuk ellátása közben hatósági személynek számítottak. A szakmai üzemeltető szervezetek, valamint a Magyar Királyi Állami Rendőrség és a Magyar Királyi Vámőrség kirendelt közegei kötelesek voltak követni a gondnokságot irányító reptéri csendőrség utasításait, amennyiben az nem ütközött saját testületük szolgálati szabályzatába. ${ }^{32}$

A reptérgondnokság, illetve a feladatait ellátó csendőr különítmény feladatköre kiterjedt az üzemmenet rendje és az üzembiztonsági szabályok betartatására, az ügyeleti szolgálat ellátására, az induló és érkező repülőgépek és okirataik átvizsgálására, a repülőgépek indítására és fogadására. Felügyelte a rádió-, a műszaki-, a tủzoltó- és az egészségügyi szolgálat munkáját. Ốrizte az objektumot és fenntartotta a rendet. Díjfizetés ellenében gondoskodott a repülőgépek tárolásáról, a kisebb javítások elvégzéséről, az üzemanyag feltöltésről. Az ügyeletes csendőr forgalmi naplót és eseménynaplót vezetett, melybe minden üzemszerú, vagy rendkívüli eseményt rögzített, felhasználva a nemzetközi reptéren szolgálatot 
ellátó rendőr vagy vámőr közegek adatait is. Ennek a kivonatát minden reptéri csendőrkülönítmény havonta megküldte a Mátyásföldi repülőtér gondnokságának, amely ezt saját adataival kiegészítve felterjesztette a légügyi hatóságnak (KEM XI. osztály). Ez szolgált később a KSH vagy a nemzetközi repülőszervezet számára a légi forgalommal kapcsolatos statisztikák összeállításánál. ${ }^{3}$

Kisebb szabálytalanságok esetén a reptéri csendőrkülönítmény saját hatáskörében intézkedett, ha pedig valamilyen komolyabb ügy elbírálására már nem volt hatásköre a tényállás jegyzőkönyvi rögzítése után tájékoztatta az arra jogosult hatóságot. Nem büncselekménynek minősülö kötelességszegés esetén 120000 koronáig terjedő rendbírságot szabhatott ki, ami ellen a KEM XI. osztályához lehetett fellebbezni. A beszedett bírságokat a hazai aviatika fejlesztésére fordították. ${ }^{34}$

$\mathrm{Az}$ 1924. III. 9-én kiadott KEM rendelet ${ }^{35}$ rögzítette, hogy légi jármủ részére alkalmassági engedélyt kell kérni a légügyi hatóságtól, amely a naptári év végéig szólt, és a következő évre egy újabb felülvizsgálat után tudták azt megújítani a tulajdonosok. Minden repülőgépnek magával kellett vinnie a közlekedésre jogosító okiratokat (alkalmassági igazolás, lajstromkivonat, eseménynapló, amely a repülési tevékenységet tartalmazta, légijárómü-napló, amely a szerkezeti adatait, állapotát, az elvégzett javításokat rögzítette, a motorkönyv, amely a hajtómú adatait és a rajta elvégzett szereléseket dokumentálta). ${ }^{36}$

A kísérő iratok mellett a gépek csak az előírt repülő felszereléssel közlekedhettek (elsősegély-dobozt, javítóeszközök, tüzoltó készülék, vízi gépek esetében mentőeszköz, éjszakai repülés esetén fényjeladó). Nappal 500, éjjel 100 kilométernél hosszabb vagy a tengerparttól 50 kilométerre eltávolodó repülés esetén a pilóta mellett egy I. osztályú szakszolgálati engedéllyel rendelkező kísérőre volt szükség, aki az útirány megtartásáért felelt. Fele ekkora távolságok esetén egy II. osztályú kísérőnek kellett jelen lennie. A szabályokat megszegőkkel szemben, büncselekménynek nem minősülö kihágás esetén $120000 \mathrm{~K}$ bírság vagy 15 nap elzárás volt kiszabható. ${ }^{37}$

Hosszas előkészités, szakmai és politikai egyeztetések után 1924. IV. 10-én a kereskedelemügyi tárca keretén belül rendelettel felállították a Magyar Királyi Légügyi Hivatalt (LÜH). ${ }^{38}$ Ez vette át a légiforgalmi osztály feladatkörét, és személyi állományát, és egyben megkapta a légügyekkel kapcsolatos korábbi miniszteri jogköröket is. A LÜH az eredeti tervek szerint a kereskedelemügyi tárcától független kormányföhivatalként jött volna létre, mivel azonban ez a szervezet volt a titokban fenntartott repülés irányítója, a rejtés érdekében megfelelőbbnek látszott, ha formálisan a KEM alá rendelik. ${ }^{39}$

A Magyar Királyi Légügyi Hivatal, egyrészt ellátta az első fokú légügyi hatóság szerepkörét és kezdeményezően közremüködött a repüléssel kapcsolatos témák szabályozásában, másrészt, felügyelte az alsóbb szintủ hatóságok, a reptérgondnokságok tevékenységét, illetve a szakigazgatással kapcsolatos napi operatív teendőket végezte. A LÜH személyzetét mindössze 20 tisztviselő alkotta, különböző alárendelt intézmények keretében azonban további 178 fő vett részt a munkájában (ebből 104 rejtett státuszú katona volt). ${ }^{40}$

A Magyar Királyi Légügyi Hivatal újraszabályozta a légi ellenőrző szolgálat müködését. A mátyásföldi vámreptér mellett további három leszállóhelyet jelölt ki, amelyeket a külföldi gépek tervezett módon igénybe vehettek (Szombathely, Miskolc, Szeged), mellettük szükségreptérként használhattak további négy leszállóhelyet (Albertfalva, Székesfehérvár, Debrecen, Pécs,). A külföldi gépek a légi kapuk között csak a tiltott területeket elkerülő, illetve a kötelezö leszállásra kijelölt vámrepteret közbeiktató legrövidebb útvonalon közlekedhettek. ${ }^{41}$ (II.sz. melléklet)

Az engedély nélkül áthaladó gépek esetében a légi ellenőrző szolgálat csak feljegyzést készített, és összesító jelentést tett, katonai gép észlelése esetén azonban azonnal tájékoztatta a legközelebbi honvéd parancsnokságot, a területileg illetékes reptérgondnokságot és a Magyar Királyi Légügyi Hivatalt is. Ilyen esetben a nemzetközileg elfogadott szabályoknak megfelelően leszállásra szólították fel a gépeket, fényjelző lövedékekkel vagy színes füstöt árasztó rakétákkal. Ha nem engedelmeskedtek, a légi ellenörzés elvileg bármilyen más eszközt is felhasználhatott a leszállításukra, a gyakorlatban azonban erre nem voltak megfelelő eszközei. Idegen katonai gépekre tüzet nyitni csak a honvédelmi miniszter közvetlen parancsa esetén, vagy egy körzetre érvényes korábbi általános honvédelmi miniszteri engedély alapján lehetett, tiszti beosztású személy utasítására. ${ }^{42}$

A LÜH 1924 nyarán lépéseket tett a pilótaképzés bővítése érdekében. Az alapkiképzésen átesett személyzet Szegedre került, a HÁRY László légügyi főfelügyelő (őrnagy) irányítása alatt álló II. és III. fokú tanfolyam elvégzésére. Székesfehérváron szintén pilóta és megfigyelő képzés kezdődött. Az 19241925-ös idényben a három bázison 58 föt iskoláztak be, közülük 24 fố fejezte be a kiképzést, és 54 fö részesült utánképzésben. A nemzetközi ellenőrzés kijátszása érdekében a kiképzés alatt álló növendékek egy-egy csoportja minden bázison próbacsendőrként szerepelt. Formálisan a csendőrség személyi állományába tartozott, csendőr egyenruhát hordott, valójában azonban katonai pilóta volt. ${ }^{43}$

\section{Katonák és csendőrök közremúködése a polgári repülésben}

A nemzetközi és a hazai légi forgalom bővülése, illetve a LÜH felállítását követően a légügyi irányítás átalakulása nyomán újraszabályozták a reptérgondnokságok és az ezek keretében múködö repülötéri csendőrkülönítmények tevékenységét. Az újraszabályozáskor összefoglalták néhány témában és az új helyzetnek megfelelően módosította a légiközlekedésre és a légtérhasználatra vonatkozó korábbi szabályozást. $^{44}$ 
A repülőtereken dolgozó polgári alkalmazottakat (a posta távírásza és az ügyeletes orvos kivételével) formálisan elbocsátották, lehetővé téve számukra, hogy próbaszolgálatos csendőrként maradhassanak, akik egy év után a VECSOG rendes állományába kerültek. Így a légierő rejtett személyzete is teljes egészében a csendőrség égisze alá került. Hivatalosan ezt azzal indokolták, különösen a SZKEB megfigyelök számára, hogy a csendőrség sokkal megbízhatóbban tudja ellátni a rendfenntartás és az őrzés mellett a repterek üzemeltetését is, mint a polgári alkalmazottak. Ebben természetesen volt igazság is, ismerve a csendőrség fegyelmezettségét, de a változás alapvetően a légierő állományának jobb rejtését szolgálta. ${ }^{45}$

A rendelet értelmében a reptéri csendőrkülönítmények látták el a reptérgondnokságok területén minden légügyi vonatkozású tevékenység felügyeletét. A csendőr különítmények székhelye általában megegyezett a hét csendör kerület (egyben a hét honvéd vegyesdandár) központjával. A budapesti gondnokság állomáshelye értelemszerúen a központi vámreptér, Mátyásföld volt. A repülötéri csendőr különítmények felettes szerve a szolgálat ellátása szempontjából nem a területileg illetékes csendőrkerületi parancsnokság volt, hanem közvetlenül a Magyar Királyi Légügyi Hivatal. ${ }^{46}$

A repülőtéri csendőrség, mint alsófokú légügyi hatóság közigazgatási feladatokat, mint a központi repülőtér üzemeltetője légi forgalmi irányítási feladatokat, mint a hatályos légiközlekedési szabályok betartatója pedig légi rendészeti feladatokat látott el. Hatásköre a gondnokságok egész területére kiterjedt, felügyelte a magánrepülőterek forgalmát, illetve az alkalmankénti repüléseket (bemutatók, versenyek), és saját hatáskörben esetenként fel- és leszállási engedélyeket adott ki. A repülő balesetek elsődleges kivizsgálása, megfelelő szakértők bevonásával szintén a reptéri csendőr különítmény hatáskörébe tartozott. ${ }^{47}$

A repülőterek irányítása során a különítmény parancsnoka készítette el a mindenkire érvényes helyi szabályozást. A reptereken csak olyan személy mozoghatott szabadon, akinek erre a csendőr különítmény parancsnokától írásbeli engedélye volt. A napkeltétől napnyugtáig tartó szolgálat során minden alkalmazott és a reptéren munkát végző személy (postatiszt, rendőr, vámőrr, orvos, takarító) köteles volt követni a csendőr parancsnok utasításait. Repülögép, hazai vagy külföldi, csak az ügyeletes csendőr zászló- vagy tárcsajelére indulhatott, miután átesett a személyzet, az utasok és a szállított áruk kötelezö ellenőrzésén. ${ }^{48}$

Kisebb szabálysértések, kötelességmulasztások esetén a repülőtéri csendőrség járt el az elkövetővel szemben, joga volt kisebb összegü helyszíni bírság beszedésére is. A csendőr parancsnok eljárásával szemben a repülötéri panaszkönyvben lehetett kifogást emelni, vagy közvetlenül a Magyar Királyi Légügyi Hivatalnál fellebbezhettek az érintettek. A LUH illetékesei mindkét esetben felülvizsgálták a reptéri csendőrség eljárását. Súlyosabb kihágás vagy büncselekmény elkövetése esetén a csendőrség őrizetbe vette a gyanúsítottat, jegyzőkönyvezte az esetet, és átadta az ügyet a területileg illetékes rendőrhatóságnak a bünvádi eljárás megindítására. A repülőterekkel, a légiközlekedéssel kapcsolatos eseményekről (baleset, kényszerleszállás, büncselekmény, rendkívüli fel- és leszállás stb.) csak a Magyar Királyi Légügyi Hivatal, vagy a reptéri csendőr különítmény parancsnoka adhatott információkat magánszemélyeknek vagy a sajtónak.

A repülőtéri csendőrség tehát kettős funkciót töltött be. Egyrészt a hivatalos, polgári légügyekkel kapcsolatos szerepkört, másrészt a katonai repülés rejtésével összhangban a honvéd repülőtisztek és katonák csendőrként való foglalkoztatását. Mátyásföldön, Szombathelyen, Szegeden és Miskolcon például a helyi csendőr különítmény parancsnokai rejtett státuszú honvéd repülőtisztek voltak. ${ }^{50}$

A polgári repülés és az annak irányítását és felügyeletét ellátó reptérgondnokságok, repülőtéri csendőrkülönítmények helyzetében, 1926-ban számottevő változás következett be. A legyözött országok aviatikáját súlyosan megterhelö, nagy versenyhátrányt okozó 9-es szabályt a párizsi légügyi egyezmény váltotta fel, amely ugyan még mindig tartalmazott bizonyos korlátozásokat a polgári repülés terén, de az már inkább csak a katonai gépek teljesítményi mutatóival rendelkező gépek gyártására és beszerzésére vonatkozott. Felfegyverzett gépek tartását pedig tovább is tiltották a legyőzött országoknak. A Nagykövetek Tanácsa, illetve Németország, Ausztria és Magyarország kormányai között megkötött egyezmény lehetővé tette a polgári légi forgalom, a sportrepülés és a tudományos célú repülés nagyobb mértékủ fejlesztését. ${ }^{51}$

A Magyar Államkincstár 1926 júniusában megvásárolta a Mátyásföldi Közforgalmi Repülőteret és azonnal hozzákezdett a bővítéséhez és korszerüsítéséhez, új hangár és nagyobb mühely építéséhez. Rendszeres nemzetközi forgalmat bonyolított a Nemzetközi Légiforgalmi Rt. (CIDNA), a Párizs-Mátyásföld-Konstantinápoly útvonalon, de állandó vendégnek számítottak a német és az osztrák légitársaság gépjei is a magyar reptereken. ${ }^{52}$

Az MLRT rendszeres postajáratokat indított Miskolc, Debrecen, Szeged, Nagykanizsa felé. A vállalat szolgáltatásait számos különböző területen vették igénybe, bemutató és propaganda repülések esetében, de az árvíz elleni védekezés során is. A vízügyi szakemberek a magasból is tájékozódhattak a folyók állapotáról, illetve repülögépekről rendszeres fényképfelvételeket készítettek az aktuális árvízi helyzetről. A magyar légi forgalom menetrendszerü járatai 1922 és 1928 között 11095 repülést teljesítettek, miközben 18215 utast 1200114 kg küldeményt szállítottak. Ugyanez idő alatt alkalmi járatok és helyi repülések során 3397 felszállást hajtottak végre 6702 fö utassal. Egyedül 1928-ban a magyar 
légi forgalom statisztikájában 2534 felszállás, 694225 megtett kilométer, 4229 utas és $343231 \mathrm{~kg}$ rakomány szállítása szerepelt. ${ }^{53}$

Az 1926-tól jelentős mértékben megnövekvő légi forgalom indokolttá tette a repülötéri szolgálatok bővítését. A légierő fejlesztésének valamelyest szélesedő mozgástere miatt több katonai repülöt nem kívántak a reptérgondnokságokhoz vezényelni, ezért a repülőtéri csendőr különítmények személyi állományát igazi csendőrökkel egészítették ki. Miközben a légügyi szakfeladatok ellááását továbbra is csendőrségi állományba átvett honvédtisztek és altisztek végezték, a reptérgondnokságok személyzete általában egy csendőr altiszttel és kettő-négy csendőrrel bővült, akik elsősorban a rendészeti és örzési tevékenységet láttak el. A központi vámrepülőtér, Mátyásföld parancsnokságára egy csendőrtiszt került, aki korábban az 1. budapesti csendőr kerület 7. alsódabasi szárnyának parancsnok-helyettese volt. Rajta kívül a repülötéri csendőr különítmény személyi állományát három rejtett státuszú honvédtiszt, három honvéd altiszt és 12 honvéd, illetve két valódi csendőr altiszt és hat csendőr képezte. ${ }^{54}$

A légügyi fejlesztések terén további lehetőségeket adott, hogy 1927. III. 31-én megszünt Magyarország közvetlen nagyhatalmi ellenőrzése, a SZKEB képviselői eltávoztak az országból. A pénzügyi ellenörzés fennmaradt, ezt a Nemzetek Szövetsége szakértői vették át, akik nem gyakoroltak közvetlen felügyeletet, csak a magyar állam által átadott adatok áttekintése alapján készítették el a jelentéseiket. A pénzügyi transzparencia miatt azonban továbbra is gondot kellett fordítani a haderő egy részének rejtésére, illetve be kellett tartani a rendvédelmi szervezetek létszámkorlátozását is.

A nemzetközi légi forgalom mellett jelentősen megélénkült a hazai szabadidős repülés, különböző légi bemutatók szervezése, sportrepülő egyesületek tevékenysége. Mindez fokozott mértékủ feladatot rótt a repülötéri csendör különítményekre. Mátyásföldön, 1928. V. 17-én nagyszabású repülőnapot rendeztek. Az esemény szervezöje a Magyar Atlétikai Club motorsport osztálya volt. A bemutatón részt vettek többek között a szegedi szombathelyi és repülőiskola növendékei, valamint a Müegyetemi Sportrepülő Egyesület tagjai, összesen 15 repülögép szerepelt a programban. A repülőnapot 15000 nézö tekintette meg. A rendezvény fövédnökei $H A B S$ BURG József Ferenc és Albrecht királyi hercegek voltak. Megjelent Mátyásföldön nagybányai HORTHY Miklós kormányzó is, annál is inkább, mert a pilóták sorában ott volt idősebb fia, nagybányai HORTHY István is, aki látványos mürepülő bemutatót hajtott végre. Az esemény biztosítására, a nagy tömeg mozgásának irányítására, biztonságának felügyeletére nagyobb számú rendőrt vezényeltek ki Budapestről, illetve a VECSOG és a környező őrsök személyi állományából, de a program lebonyolításával kapcsolatos reptéri teendőket alapvetően a mátyásföldi repülőtéri csendőr különítménynek kellett megoldania, melyet az esemény idejére néhány fövel megerösítettek. ${ }^{55}$

A repülötéri csendőrség, a maga öt különítményével, 96 fös létszámával (közte 14 tiszt és 18 altiszt), melyből a rejtett státuszú honvédegyének mellett mindössze 30 fő volt valódi csendőr (közte egy tiszt és hét altiszt), csak egészen kis részt képezett a csendőrség mintegy 12000 fös létszámán belül, a 7 csendőr kerület 30 osztálya, 93 szárnya, 209 szakasza és 853 örsének sorában. Tevékenységük összetett jellege (légi irányítás, légügyi közigazgatás, légi rendészet), illetve, hogy feladataikat nagy (esetenként nemzetközi) nyilvánosság elött látták el jelentős szerepet biztosított számukra. ${ }^{56}$

Időközben átszervezések történtek a Magyar Királyi Kereskedelemügyi Minisztériumban, a légügyi fejlesztések rejtése érdekében a LÜH a tárca V. osztályaként müködött tovább, változatlan feladatkörrel. A hivatal állományát 147 fö alkotta (köztük 39 fö tiszti beosztásban). A csendörség keretében ekkor 548 fö rejtett státuszú repülő katona szolgált, közülük 64 föt vezényeltek a reptérgondnokságokhoz. ${ }^{57}$

A légiközlekedésre vonatkozó rendelkezéseket 1929-ben ismét módosították, az új jogszabály azonban csak néhány kisebb szövegkorrekciókból állt, ami megkönnyítette az előírások értelmezését és alkalmazását. ${ }^{58}$ A katonai fejlesztések rejtésének érdekében bizonyos változások következtek be az idegen repülők számára kijelölt tiltott övezetek határának megjelölésében. A csepeli zónát, amely korábban csak a sziget északi részét foglalta magába, déli irányban megnövelték, a Háros-sziget délnyugati csúcsa és Soroksár déli kijárata vonaláig. ${ }^{59}$

A légi forgalom bővülésével összhangban bővült a reptérhálózat is. A korábbi reptérgondnoksági megbízott helyett teljes gondnoki testület és csendőr különítmény került a pécsi és debreceni repülőtérre. További három reptéri csendőr különítmény is felállításra került. Az egyik Csepelen a vízi repülő állomáson, amely a bővülő nemzetközi forgalom számára vámrepülőtérként müködött. A másik két különítmény pedig Kaposvárra és Nyíregyházára települt, ahol jelentősebb rejtett katonai fejlesztések folytak. A Mátyásföldi repülötér 1930 őszén naponta négy-négy magyar és francia, hetente pedig négy brit gépet fogadott, valamint minden napra jutott nem menetrend szerint közlekedő járat is. Rendszeres légiposta járatok repültek Szegedre, Miskolcra és Szombathelyre, valamint a Budapest-Nyíregyháza-Debrecen és a Budapest-Kaposvár-Pécs útvonalon. Mivel az MLRT anyagi gondokkal küzdött, a vállalatot újraalapították, most már többségi állami tulajdonú cégként. ${ }^{60}$

A korábbinál nagyobb figyelmet kapott a sportrepülés, amelyre, mint a légierő lehetséges személyi utánpótlására tekintettek. Különösen GöMBÖs Gyula honvédelmi miniszter (később kormányfö) szorgalmazta a sportrepülő egyesületek létrehozását. Az ország pénzügyi ellenőrzése miatt ezek a Magyar Királyi Vallás- és Közoktatásügyi Minisztérium költségkeretéből kaptak állami támogatást. A következő években több szervezet is alakult: a Budapesti Sport Egyesület - BSE (Mátyásföld), a Délvidéki Aero Club (Szeged), a Baranya-Pécsi Aero Club (Pécs), a Debreceni Aero Club (Debrecen), a Mátra- 
vidéki Aero Club (Miskolc) és a Somogy Megyei Aero Club (Kaposvár), illetve a gyöngyösi, budaörsi, Farkas-hegyi vitorlázórepülő egyesület. 1930 -ban 12 városban tartottak nagyobb repülöbemutatót. ${ }^{61}$

A katonai fejlesztés érdekeire figyelemmel megduplázták az egyes repülőtereken müködő reptérgondnokságok létszámát. A testületek egyik fele katonai repülőkből állt, akik a légierő rejtett alakulatainak helyi személyzetét alkották. A reptérgondnokságok személyi állományának másik felét a korábban felállított reptéri csendőr különítmények képezték, amelyek a polgári repülés ügyeit intézték. Ezek változatlanul vegyes összetételủek voltak, ahol rejtett státuszú katonák és valódi csendőrök egyaránt szolgáltak. ${ }^{62}$

\section{Önálló csendőr-parancsnokság a polgári repülés irányításában}

A reptérgondnokságok kétféle funkciójának (személyzetének) egyértelmű elhatárolása, érdekében Mátyásföldön felállították a reptéri csendör különítmények központi parancsnokságát. A parancsnok alá két rejtett státuszban lévő honvédtiszt és két honvéd altiszt, valamint két valódi csendőr altiszt, illetve 12 rejtett állományú honvéd és nyolc csendőr tartozott. A Mátyásföldi Repülötér parancsnoka egyben elöljárója volt az összes repülőtéren müködő csendőr különítménynek, illetve a különböző repülő rendezvények (bemutatók, versenyek, külföldi repülő delegációk fogadása stb.) biztosítására kirendelt csendőr egységeknek.

1931. VII. 15-16-án, amikor a magyar óceánrepülők, az Amerikából leszállás nélkül Magyarországra repülő és a „Justice for Hungary” (Igazságot Magyarországnak) elnevezésủ gép fogadására készültek a Mátyásföldi reptéren, hatalmas tömegre számítva kivezényelték a budapesti, Budapest-vidéki és a mátyásföldi rendőrség 1298 rendőrét, valamint a VECSOG és a környező őrsök mintegy 150 csendőrét, akiket az esemény idejére mátyásföldi csendőr különítmény parancsnoksága alá rendeltek. ${ }^{63}$

Hasonló volt a helyzet 1932. VI. 15-én, amikor az Atlanti-óceánon átrepülő magyar pilóták 1932. V. 21-ei tragikus repülőbalesete nyomán megérkezett Magyarországra az az olasz repülőgép (Fiat BR3), amelyet az olasz vezetés a magyar óceánrepülő iránti tisztelete kifejezéséül ajándékozott a magyar kormánynak. A „Giustizia per l’Ungheria” (Igazságot Magyarországnak) nevü gépet hatalmas tömeg fogadta és jelen volt több miniszter (köztük GöMBÖs Gyula), illetve a LÜH vezetője is. A program zökkenőmentes lebonyolítását és a rend fenntartását a Mátyásföldi Repülőtér csendőr különítményének a parancsnoka koordinálta, akinek a szerepét az eseményről hírt adó lapok is kiemelték. ${ }^{64}$

A katonai aviatika rejtése érdekében az 1930-as évek elején többször is átalakították a Magyar Királyi Légügyi Hivatalt. Az intézmény 1931-ben még a kereskedelmi tárca V., 1932-től a III., 1934 őszétől a VII., 1936-ban pedig a XI. szakosztályaként müködött. Ez a sok átszervezés szinte követhetetlenné tette a nemzetközi megfigyelők számára a LÜH müködését, létszámváltozásait, pénzfelhasználását. ${ }^{65}$

A repülés biztonsága, ugyanakkor a katonai kommunikáció javítása érdekében a KEM 1933-ban újraszabályozta a rádiószolgálat ellátását, a repterek egymás közötti rádióforgalmát, a légi járművekkel való kapcsolattartást (irányjelző és helyzet meghatározó szolgálat, reptér és repülőgép közötti összeköttetés, repülőgépek egymás közötti kommunikációja), valamint a légi meteorológiai szolgálat müködését. Ezzel egyidőben a LÜH átvette a rádiószolgálat ellátását a Magyar Királyi Postától a Mátyásföldi repülőtéren. Ekkorra már olyan mértékben megnőtt a rádióforgalmazás, hogy egy adókészülékkel nem tudták ellátni. Míg a mátyásföldi rádiósok 1926-ban 4604 hírváltást hajtottak végre, addig 1932-ben már 30147 üzenetet továbbítottak. ${ }^{66}$

A nemzetközi forgalom számára is fontos reptereken rádió-iránymérő állomásokat létesítettek (gonio-állomás), melyek segítették a gépek navigálását. Ilyen berendezés müködött Szombathelyen, Székesfehérváron, Szegeden és Mátyásföldön. ${ }^{67}$

Megváltozott a magyar repülőgépek jelzésrendszere. Az 1933. IV. 19-én kiadott rendelet értelmében, a „H-M” ország azonosítót a „HA-” váltotta fel, utána ugyanúgy 3 betü következett, a gépek egyéni lajstromjele. A betüsort a szárny alsó és felső felületére, valamint a törzs két oldalára kellett felfesteni. A katonai gépeken a vezérsík kormányfelületét nemzeti színekre festették. A polgári gépeken, a vezérsíkon egy nagy „H” betű jelezte a hovatartozást. ${ }^{68}$ Módosult a magyar légtérbe való be- és kirepülés során használható légi kapuk jegyzéke is. Az új szabályozás szerint a magyar légtér határait Komárom, Hegyeshalom, Szombathely, Zákány, Kelebia, Battonya, Biharkeresztes és Hidasnémeti térségében lehetett átlépni, egy $5 \mathrm{~km}$ széles folyosón, a határon átvezető foútvonalat vagy vasútvonalat követve. ${ }^{69}$

Ezzel egyidőben szigorításokat vezettek be a légtérhasználati szabályokban is. 1933. XII. 22-én új, átfogó szakminiszteri rendelet jelent meg a külföldi légi jármüvek közlekedéséről. ${ }^{70} \mathrm{~A}$ polgári gépek berepülési kérelme esetén a LÜH már nem adta ki automatikusan az engedélyt, hanem a személyzetet előzetesen leinformálta. A légi ellenőrzést végző szervezetek a légi eseményekkel kapcsolatos jelentéseiket három helyre küldték meg: saját kerületi parancsnokságuknak, a felügyelő minisztérium illetékes 
osztályának és a Magyar Királyi Légügyi Hivatalnak. A csendőrség által készített jelentéseket így közvetlenül megkapta a csendőrkerületi parancsnokság, a belügyi tárca VI. b. osztálya és a LÜH is. A Magyarországgal légügyi egyezményt kötött államok (Ausztria, Németország, Olaszország, Lengyelország) polgári gépjei előzetes engedély nélkül, de a légiforgalmi szabályokat betartva használhatták a magyar légteret. ${ }^{71}$

Más államok gépjeinek berepülési engedélyre volt szüksége, amely megszerzéséhez tájékoztatást kellett adni a LÜH számára a gép hovatartozásáról, felségjelzéséről, lajstromjeléről, típusáról, a motor azonosítószámáról, lóerejéről, illetve a gépen lévő egyéni jelzésekről. Közölni kellett a tulajdonos és üzemeltetô, illetve a hajózó személyzet nevét, állampolgárságát, lakóhelyét, valamint az utasok nevét. Meg kellett adni az indulási helyet, a célállomást, a magyarországi tervezett útvonalat. Ez alapján adta ki a LÜH az átrepülési engedélyt, meghatározva a használható légi kapukat és a követendő útvonalat. Minderről a Magyar Királyi Légügyi Hivatal a Magyar Királyi Belügyminisztériumot is tájékoztatta.

Katonai légi járművek terén a kisantant államok és a Szovjetunió gépjeinek átrepülését megtiltották. A többi állam esetén a LÜH a honvédelmi tárcával egyeztetve adta ki a belépési engedélyt. Fegyver, löszer, robbanóanyag, vegyi harcanyag szállításához a belügyi tárca külön engedélyét kellett kérni, melyben megjelölve a veszélyes rakomány szállításánál alkalmazott biztonsági rendszabályokat, és biztosítva, hogy ezekhez az eszközökhöz és anyagokhoz a repülés közben a személyzet nem fér hozzá. Személyi védőfegyver viseléséhez elegendő volt a LÜH jóváhagyása. Fényképezőgép vagy postagalamb szállítására szintén a Magyar Királyi Légügyi Hivatal adott engedélyt, ezeket azonban olyan módon kellett elhelyezni a repülőgépben, hogy menetközben a személyzet ne férhessen hozzájuk. ${ }^{72}$

Ha egy külföldi légi jármü jogosulatlanul használta a légteret, vagy tiltott terület fölé repült be leszállásra szólították fel. Nappal fehér füstöt, éjszaka fehér csillagokat kibocsájtó jelzőlövedék fellövésével. A szabályosan közlekedő légi járműveket is leszállásra hívhatták fel ellenőrzés céljából. A leszállás után a reptéri csendőr különítmény átvizsgálta a gépet, nem folytatott-e felderítést, titkos képrögzítést. Az ellenőrzés eredményét polgári gép esetén a légügyi hatósághoz továbbították. Katonai gép esetén először a területileg illetékes vegyesdandárt értesítették, amely indokolt esetben kémelhárító közegeket küldött a helyszínre. Ha az érintett légi jármü a felszólítás ellenére nem szállt le a légügyi szervek másodszor is figyelmeztették. Amennyiben erre sem reagált, bármilyen eszközzel (akár fegyveres erővel is) a földre lehetett kényszeríteni, békeidőben azonban a fegyverhasználathoz honvédelmi tárca közvetlen engedélyére volt szükség. ${ }^{73}$

1935-ben a korábbi ideiglenes szabályozások után új, átfogó rendelkezést adtak ki a légi ellenőrző szolgálat ellátására. Az ország feletti légi tevékenység ellenőrzése a LÜH hatáskörébe tartozott, amely ennek végrehajtásához különböző hatóságok, rendvédelmi szervezetek közremüködését vette igénybe. A csendőrség, rendőrség, folyamőrség és határőrség minden felállított őrsége vagy mozgó járőre köteles volt figyelni a légteret, és naponta jelenteni az észlelt légi tevékenységet a helyi parancsnokságának. Olyan körzetekben, ahol sem honvéd alakulat, sem rendvédelmi testület szervezeti egysége nem állomásozott a belügy javaslatára - a helyi tüzoltóságot is bekapcsolták a légi ellenőrző szolgálatba. Az őrsöktől beérkező adatok alapján a helyi parancsnokságok havi összesítéseket készítettek, amit egyrészt a kerületi rendőr, csendőr, határőr parancsnokságokra terjesztettek fel, másrészt megküldtek a LÜH számára. ${ }^{74}$

Ha felmerült, hogy egy gép jogtalanul használja a légteret, vagy idegen katonai légi jármüvet észleltek, esetleg egy külföldi gép elhagyta a szokásos légifolyosót, vagy egy tiltott zóna felett repült át, arról azonnal értesíteni kellett az illetékes reptérgondnokság csendőrkülönítményét, a Magyar Királyi Légügyi Hivatalt, katonai gép esetén a vegyesdandár parancsnokságát is. Repülőtéren kívüli leszállás esetén a helyi rendvédelem képviselői megvizsgálták a landolás okát, ellenőrizték a gép és a személyzet iratait, és ha mindent rendben találtak továbbengedték a repülögépet, de bejelentést tettek az esetről a repülőtéri csendőr különítménynek, illetve a Magyar Királyi Légügyi Hivatalnak. Ha a gép jogosulatlanul közlekedett, hiányos volt a dokumentációja, vagy ha felmerült a csempészés vagy kémkedés gyanúja, vissza kellett azt tartani, értesíteni a helyi közigazgatási hatóságot, amely lefoglalta a gépet, és tájékoztatni a repülőtéri csendőrséget, amely őrizetbe vette a személyzetet. Katonai gép esetén a vegyesdandár foglalta le a légi jármüvet és a rajta található fegyverzetet vagy fényképező felszerelést. A következő évben a légtérellenőrző szolgálat irányítását a Magyar Királyi Légügyi Hivataltól átvette az újonnan felállított Országos Légvédelmi Parancsnokság, a rendvédelmi erők azonban továbbra is közremüködtek a szolgálat ellátásában. ${ }^{75}$

1935. VIII. 8-án személyi változás következett be. A betegsége miatt leváltott légügyi föigazgató utódját kinevezése alkalmával tábornokká léptették elő. ${ }^{76}$ 
Mátyásföldön, 1936. VI. 14-én újabb nagyszabású repülőnapra került sor. A hazai motoros és vitorlázó repülő, ejtőernyős ugrók mellett a programban szerepelt 10 olasz vadászrepülögép bemutatója is. Az eseményen részt vett nagybányai HORTHY Miklós kormányzó és Don Pierro CoLONNA herceg, a budapesti olasz követ is. A nézőszám megközelítette a 60000 főt. A repülőnap megszervezése, az esemény biztosítása, a rend fenntartása, a hatalmas tömeg mozgatása alapvetően a rendőrségre és a csendőrségre hárult. A bevont csendőr egységeket a Mátyásföldi repülőtér csendőr különítménye irányította. ${ }^{77}$

1937-re a nemzetközi és a hazai légi forgalom kinőtte a Mátyásföldi repülőteret, szükségessé vált egy korszerübben felszerelt légikikötő megépítése. Ugyanakkor Mátyásföldre egyre inkább a honvédség tartott igényt a katonai repülés és pilótaképzés bővülése nyomán. Kilenc külföldi légitársaság gépjei látogatták rendszeresen Magyarországot (brit, francia, holland, német, svájci, olasz, osztrák, csehszlovák, lengyel járatok). Budapestről elérhető volt repülőgépen London, Párizs, Amszterdam, Berlin Zürich, Róma, Bécs, Prága, Varsó, Belgrád, Athén, Bukarest. A Minisztertanács már 1935. IV. 11-én döntést hozott az új közforgalmi repülőtér kiépítéséről, amely végül 1937. VI. 20-án nyílt meg Budaörsön. Az új repülőtér elkészülésével felmerült a kérdés, hogy a létesítményt milyen szervezet üzemeltesse, polgári alkalmazottakból toborzott szolgálat, a budapesti rendőrség, amely egyébként is az útlevél ellenőrzést végzi, vagy a korábbiakhoz hasonlóan egy repülőtéri csendőrkülönítmény. Vita zajlott a kérdésről a fővárosi közgyűlésben is. A LÜH főnöke 1937. V. 26-án külön átiratban fordult a belügyminiszterhez, amelyben azt kérte, hogy továbbra is a csendőrség adja a közforgalmi reptér üzemeltető szolgálatát, mert már e téren megfelelö tapasztalatai vannak, komoly tekintéllyel rendelkezik és tökéletesen megbízható. ${ }^{78}$

A Budaörsi repülőtéren új reptérgondnokságot állítottak fel, amelyhez átvezényelték Mátyásföldről az ottani repülőtéri csendőr különítményt. A nemzetközi légi forgalmat kiszolgáló rádióadót a közeli Tétényi fennsíkon állították fel. A berendezést a Magyar Királyi Posta távírászai kezelték. Az objektum őrzését az albertfalvai és nagytétényi őrsről vezényelt csendőrök látták el. A rádió-iránymérö állomás a repülőtér területén müködöttt. ${ }^{79}$

A reptér megnyitását látványos légi parádé kísérte. A létesítményt nagybányai HORTHY Miklós kormányzó adta át, jelen volt az ünnepségen pusztaszentgyörgyi és tetétleni DARÁNYI Kálmán miniszterelnök és több kormánytag, a külföldi vendégek között Erhard MILCH német légügyi államtitkár, az olasz és az osztrák követ, a Magyarországra akkreditált katonai attasék. Az érdeklődő közönség létszáma a sajtó szerint megközelítette a 100000 föt. A repülő programban a magyar gépek és ejtőernyős ugrók mellett német, osztrák és olasz kötelékek is szerepeltek. ${ }^{80}$

Magyarország nemzetközi pénzügyi ellenörzése 1938. II. 27-én megszünt. A kormány 1938. III. 1jén 1000000000 pengős haderőfejlesztő programot indított. Az 1938. VIII. 22-én megkötött Bled-i egyezményben a kisantant államok elismerték Magyarország fegyverkezési egyenjogúságát, ezzel eltủnt a trianoni békediktátum által állított utolsó korlátozás is a fegyveres erők megerősítése és korszerüsítése elől. 1938. IX. 1-jén a Magyar Királyi Honvédség teljes személyi állományával a nyilvánosság elé lépett. A korábban különböző intézményeknél, rendvédelmi szervezeteknél rejtett státuszokban szolgálatot teljesítő katonák ismét honvédségi beosztásokba kerültek. A haderő bevezetésre kerülő új szervezési rendjében, 1939. I. 1-től a „Magyar Királyi Légierők” új haderőnemként szerepelt. A 1939. III. 24-én kiadott kormányrendelet szétválasztotta a polgári és a katonai repülést. A Magyar Királyi Légügyi Hivatal átkerült a Magyar Királyi Honvédelmi Minisztérium közvetlen irányítása alá, míg a polgári légügyek felügyeletét továbbra is a Magyar Királyi Kereskedelem- és Közlekedésügyi Minisztérium (KKM) légiforgalmi föosztálya látta el. ${ }^{81}$

Az országban mindössze két kiépített repülőtér maradt, amely közforgalmi célokat szolgált (Budaörs, Csepel), a többit a Magyar Királyi Honvédség vette használatba. A korábbi repülőtéri csendőr különítmények állományukból kiváltak a rejtés miatt odavezényelt honvédek, akik a légierőnél kaptak új beosztást, a csendőröket pedig visszavezényelték valamilyen rendvédelmi feladatkörbe. Egyetlen repülötéri csendőr különítmény maradt ( 2 tiszt, 4 altiszt, 20 csendőr), amely a két reptér üzemeltetését irányította. A különítmény kivált a LÜH irányítása alól, és a budapesti I. csendőr kerület-parancsnokság alárendeltségébe került. A parancsnokság székhelye egy ideig még Mátyásföld volt, mert az 1938-1939es nagy esőzések hosszabb-rövidebb idöre üzemkiesést okoztak a még csak részben alagcsövezett Budaörsi reptéren, és a forgalmat ilyen esetekben Mátyásföldre irányították át. ${ }^{\mathbf{2}}$

A II. világháború kirobbanása nyomán a rendvédelmi szervezetek által korábban ellátott polgári légi ellenőrző szolgálat feladatait az Országos Légvédelmi Parancsnokság alá tartozó katonai légvédelmi figyelö- és jelentőszolgálat vette át. Ez a szervezet 1941. VI. 9-én légvédelmi központtal és 346 honi 
légvédelmi figyelőőrssel, 1944 márciusában pedig már 15 légvédelmi központtal és 550 őrssel rendelkezett. A rendvédelmi szervek a Magyar Államvasútak (MÁV) és a Folyamhajózási Rt., illetve a polgári légoltalom figyelőszolgálatához hasonlóan továbbra is részt vettek a légtér megfigyelésében, ezt a tevékenységet azonban már katonai irányítás mellett folytatták. A légi figyelő és jelentő szolgálat ellátását szabályzó „A-120” jelzésủ utasítás ezért emelte ki, hogy idegen jármü vagy valami egyéb légi esemény észlelése esetén a csendőr őrsök először a területileg illetékes honvéd hadtest vagy honvéd kerület-parancsnokságnak tettek jelentést, csak utána tájékoztatták saját csendőr kerületi elöljáróságukat. ${ }^{83}$

Az 1940-ben kiadott „A-43”-as számú honvéd határszolgálati utasítás pedig megállapította, hogy a Legfelsőbb Honvédelmi Tanács döntése alapján a hadtest-parancsnokságok indokolt esetben igénybe vehették a területükön lévő csendőr alakulatokat határszolgálati feladatok ellátására. Ez egyaránt vonatkozott a szárazföldi, a vízi vagy a légi határbiztosításra, határvédelemre. A feladat fontosságára való tekintettel, elrendelték, hogy a határszolgálatot ellátó csendőr alakulatok külön felsőbb parancs nélkül is tüzet nyithattak az ellenséges magatartást tanúsító idegen gépekre, hogy leszállásra vagy visszafordulásra kényszerítsék. Ha olyan állam repülőgépét észlelték, amellyel Magyarország hadban állt, akkor is tüzelniük kellett a repülőgépre, ha az nem folytatott támadó tevékenységet. ${ }^{84}$

A közforgalmi repülőtereket üzemeltető reptéri csendőrkülönítmény mellett, hosszas előkészítés után 1940. VI. 1-jén önálló testületként felállításra került a légi csendőrség, amely egyrészt légtér ellenőrzési és határvédelmi feladatokat látott el, másrészt légügyi igazgatási és légi rendészeti tevékenységet folytatott. Az új szervezet parancsnoksága Budaörsön müködött. (III.sz. + V.sz. melléklet) A légi csendőrség többszörös alárendeltségben müködött. Szervezési, anyagi, kiképzési, személyi, fegyelmi ügyekben a Magyar Királyi Csendőrség felügyelöjén keresztül a belügyi tárca VI. b. (csendőrségi szolgálati) és a honvédelmi tárca XX. (csendőrségi) osztálya volt illetékes felette. Operatív tevékenységét tekintve, a honvédelemmel összefüggő kérdésekben a Légierők Parancsnokságán keresztül a Honvéd Vezérkar fönökének irányítása alatt állt, a polgári repüléssel kapcsolatos teendői tekintetében pedig a KKM légiforgalmi főosztálya volt a felettes szervezete. ${ }^{85}$

Az ország területét négy légi csendőr körzetre osztották. A felosztás alapelvéül az szolgált, hogy az ellenséges (szovjet, román) légi határsértésekkel jobban veszélyeztetett keleti régióban kisebb, a viszonylagos biztonságban lévő nyugati és északi országrészben nagyobb területet fogott át egy-egy körzet. ${ }^{86}$ (III.sz. melléklet)

A légi csendőrség külön légi és földi részlegből állt. A légi részt 5 repülőgépekkel felszerelt őrs (repülő raj) képezte. Az 1. és 2. őrsöt a szolnoki, a 3. a nyíregyházi, a 4. és 5. őrsöt pedig a Budaörsi repülőtéren helyezték el. Mivel a csendőrség még nem rendelkezett kiképzett pilótákkal, ezt a feladatot ideiglenesen a légierőtől átvezényelt honvédtisztek látták el. A repülő alakulatok tevékenysége elsősorban a határok légi biztosítására, a légtérsértések, az illetéktelen légtérhasználat, a kém- és szabotázs tevékenység, illetve csempészet megakadályozására irányult. A repülö rajok rendszeres határellenőrző járőrszolgálatot folytattak. A budaörsi 4. raj feladatai közé tartozott a polgári légi forgalom Az 5. örs gépjeit elsősorban rendkívüli futár utakra, rendvédelmi (például árvízi szolgálat) és karhatalmi célokra használták. ${ }^{87}$

A későbbiekben felmerült, hogy további 2 légi csendőr körzetet és hozzá 2 új csendőr repülő rajt állítanak fel, az egyiket Észak-Erdélyben, Kolozsvár központtal, a másikat az ország délnyugati részén a Bajától Szentgotthárdig terjedő térségben. 1942-ben lépések történtek ezek megszervezésére, végül azonban anyagi problémák, repülőgép és létszámhiány miatt az V. és VI. légi csendőr körzet létrehozása elmaradt. ${ }^{88}$

A légi csendőrség földi szolgálata keretében valamennyi (katonai és polgári feladatokat ellátó állandó repülötéren, összesen 22 helyen 3-4 fös csendör különítményeket vagy 5-12 fös örsöket állítottak fel. (III.sz. melléklet) A légi csendőrség repülő részlegéhez 8 tiszt és 42 fö legénység tartozott, a földi részleg létszáma 5 tiszt és 156 fö legénység volt. ${ }^{89}$

1940. III. 1-jén — közvetlen a csendőrség felügyelöje alárendeltségében — centralizálták a közlekedési feladatköröket ellátó csendőr alakulatokat a Magyar Királyi Csendőrség Közlekedési és Híradó Osztály elnevezéssel, amely 3 közlekedési és 1 híradó szárnyból, tovább 1 müszaki alosztályból állt. Ide sorolták be önálló szárnyként az egyetlen megmaradt repülőtéri csendőr különítményt. A repülötéri szárny ekkor 3 örssel rendelkezett, a budaörsi és csepeli egység mellett folyt a szervezés az építés alatt álló Ferihegyi repülőtéren is. ${ }^{90}$

A Budaörsi repülőtér irányítását a reptérgondnokságtól az 1940. XI. 8-án kiadott rendelet értelmében egy polgári testület, a Budapesti Közforgalmi Repülőtér Igazgatósága vette át, ez gyakorolta a továbbiakban a légi kikötő üzemeltetésére, irányítására vonatkozó hatásköröket. ${ }^{91}$ A reptéri csendőrség azonban továbbra is Budaörsön maradt a légügyi igazgatási és légi rendészeti teendők ellátására. A 
repülőtérre vezényelt csendőrök pontosan és fegyelmezetten teljesítették szolgálati feladataikat, emellett azonban mindenben megfeleltek a nemzetközi forgalom igényelte elvárásoknak is. Valamennyien tudtak németül, és általában még egy utódállam nyelvén, minden váltásban voltak olyanok, akik beszéltek olaszul, franciául vagy angolul. Szolgált olyan tiszthelyettes Budaörsön, aki 8 nyelven tudott kommunikálni az utasokkal és a repülőszemélyzettel. ${ }^{92}$

Az alsó fokú légügyi hatóság jogkörét gyakorló repülötéri csendőr szárny végül csak Budaörsön és Csepelen müködött. Ferihegy üzemeltetését a Csepelről odatelepített Repülő Kísérleti Intézet vette át. 1941-re felállításra került viszont a reptéri csendőrség az erdélyi régióban, Nagyváradon, Kolozsváron és Marosvásárhelyen. ${ }^{93}$

1943 végén átszervezték a csendőrség légi és repülőtéri szolgálatát. (IV.sz. + VI.sz. melléklet) Az egyébként is a Magyar Királyi Honvédségtől kölcsönzött gépekkel és pilótákkal feltöltött csendőr repülö rajokat feloszlatták, a légi csendőrség földi őrseit és a repülőtereken szolgáló üzemeltető, illetve őrszemélyzetet a repülőtéri szárnyban vonták össze. Ekkor állították fel a Magyar Királyi Csendőrség Központi Közlekedési Parancsnokságát, amely 4 közlekedési szárnnyal (24 örs, 201 csendőr) rendelkezett. Ennek alárendeltségébe került a repülőtéri szárny. ${ }^{94}$

A repülőtéri szárny 3 szakasszal, 19 őrssel rendelkezett, személyi állományába 1944-ben 2 tiszt, 22 altiszt és 212 fổ legénység tartozott. A szárny parancsnoksága és mindhárom szakaszának bázisa Budaörs volt. Az 1. szakasz ( 7 örs, 82 csendőr) a Dunántúlon állomásozott. A 2. szakasz (6 örs, 59 csendőr) a keleti országrészben teljesített szolgálatot. A 3. szakasz (6 örs, 68 csendőr) az ország középső körzetében tevékenykedett. (IV.sz. melléklet) A német megszállás után azonban, 1944 májusában megszünt a polgári légiközlekedés, a személy áru- és postaszállítás felügyeletét is a Magyar Királyi Honvédség vette át. Ugyancsak a haderő ellenőrzése alá vonták, a sport- és szabadidős repülést is. ${ }^{95}$ 


\section{Jegyzetek:}

${ }^{1}$ HIM-HL. HM.Eln. 37. 21 688/1920., D. 11 334/1921. ; HIM-HL. TGY. 2787. I. 24-28.p.

${ }^{2}$ A Magyar Aeroforgalmi Rt. (MAEFORT) vezetője KÁROLYI László volt.

HIM-HL. HM.Eln. op.cit. D. 4700/1921. ; HIM-HL.TGY.op.cit. 2825. 13.p. ; RÉvÉsz: A légjáró. Petróczy István, az elsö magyar katonai repülö élete. 143-146.p.

${ }^{3}$ CSANÁdi — NAGyvÁradi - WinkLer: 124-125.p. ; Alkér-Ambrózy: 54.p. + 60.p. + 63.p. ; Sillay: Katonai légi jármüvek nemzetközi jogi helyzete. 128-129.p.

${ }^{4}$ HIM-HL. VKF. Eln. 1. 91/1921. ; HIM-HL.TGY. op.cit. 2787. I. 13-14.p. + 21-26.p. ; RÉvÉsz: A légjáró. Petróczy István, az első magyar katonai repülö élete. op.cit. 147.p.

${ }^{5}$ HIM-HL. HM.Eln. op.cit. D. 5695/1922. ; MOYS: Repülőtér gondnokságok, repülőtéri csendőrség a két világháború közötti időben. 230.p.

${ }^{6}$ MoYs: A Magyar Királyi Csendőrség és a rejtett Légierők kapcsolata 1924-1938. 50.p. ； SiLLAY: A légi közlekedés nemzetközi jogi szabályozása. 168-169.p. ; M. SzABó: 9.p.

${ }^{7}$ WINKLER: 504.p. ; MOYs: A polgári repülésbe rejtett Légierők. 78.p.

${ }^{8}$ HIM-HL. HM.Eln. op.cit. D. 5695/1922. ; KUNÁR-MOYS: 41.p. ; VESZTÉNYI: 214.p.

${ }^{9}$ HIM-HL. HM.Eln. op.cit. D. 19 670/1922. + 18 137/1923. ; WINKLER: op.cit. 503-504.p.

${ }^{10}$ SiLlaY: A légi közlekedés nemzetközi jogi szabályozása. op.cit. 169-170.p.

11 VESZTÉNYI: op.cit. 210-211.p. ; MoYS: A polgári repülésbe rejtett Légierök. cit. 78-80.p.

12 1922/XVII.tc. 30.§ ; 10 270/1922. (XII. 14.) ME.r. ; KonTZ: 195.p. ; Рethö: 1943. 5-15.p.

1310 270/1922. (XII. 14.) ME.r. op.cit. 192-203.p.

${ }^{14}$ KONTZ: op.cit. 196-197.p. ; 10 270/1922. (XII. 14.) ME.r. op.cit. 194-196.p.

${ }^{15}$ HIM-HL. VKF. op.cit. Eln. 1. 6117/1924.

${ }^{16} 10$ 270/1922. (XII. 14.) ME.r. op.cit. 197-203.p. ; PETHÖ: op.cit.12-15.p.

${ }^{17}$ HIM-HL. HM. Eln. op.cit. D. 15 764/1923. ; HIM-HL VKF. op.cit. Eln. 1. 6166/1924.

${ }^{18}$ SZAKÁly: 100.p. ; CSEPREghY: 147-148.p.

${ }^{19}$ HIM-HL VKF. op.cit. Eln. 1. 6117/1924. ; PARÁdI: 62.p. ; HADNAGY: 115.p.

2045 264/1924. (III. 8.) KEM.r.

${ }^{21}$ SiLLAY: A légi közlekedés nemzetközi jogi szabályozása. op.cit. 189.p. ; PALıK: 10.p.

${ }^{22}$ CSEPREGHY: op.cit. 148-149.p.

${ }^{23}$ PALIK: op.cit. 11.p. ; CSEPREGHY: op.cit. 147-148.p.

${ }^{24}$ Repülötéren kívüli fel- és leszállások engedélyezésének feltételei. 166.p.

${ }^{25}$ KUNÁR - MoYS: op.cit. 41.p. ; MOYs: Repülötér gondnokságok, repülőtéri csendőrség a két világháború közötti időben. op.cit. 230.p. ; NAGYVÁRADI - M. SZABÓ - WinKLER: 146.p.

2645 332/1924. (II. 25.) KEM.r.

${ }^{27}$ KONTZ: op.cit. 196-197.p.

2845 340/1923. (IV. 28.) KEM.r. 11.p.

${ }^{29}$ CSEPREghY: op.cit 147-148.p. ; PALIK: op.cit. 11.p.

3010 270/1922. (XII. 14.) ME.r. op.cit.

${ }^{31} 1$ 630/1924. (II. 22.) ME.r. 30-33.p. ; 45 264/1924. (III. 8.) KEM.r. op.cit. 709-720.p.

3245 264/1924. (III. 8.) KEM.r. op.cit. 712-716.p.

${ }^{33}$ Loc.cit.

${ }^{34}$ Loc.cit. 712-714.p.

3546 402/1923. (III. 9.) KEM.r.

3645 264/1924. (III. 8.) KEM.r. op.cit. 721-724.p. + 726-727.p.

${ }^{37}$ SiLLAY: A légi közlekedés nemzetközi jogi szabályozása. op.cit. 173-174.p.

3845 179/1924. (IV. 5.) KEM.r.

${ }^{39}$ KUNÁR — MOYs: op.cit. 42.p. ; 45 179/1924. (IV. 5.) KEM.r. op.cit. 745-749.p.

${ }^{40}$ A Magyar Királyi Légügyi Hivatal (LÜH) vezetőjévé VASSEL Károly légügyi igazgatót (valójában vkszt. ezredest) nevezték ki, aki már PETRóczY István nyugállományba vonulása óta, 1923. V. 18-tól a XI. osztályt vezette.

Magyarország légügyi hatóságai, egyesületei és légiforgalmi vállalatai.: 135.p. ; M. SzABÓ: op.cit. 9-10.p. ; MoYs: Repülőtér gondnokságok, repülőtéri csendőrség a két világháború közötti időben. op.cit. 231.p. ; HÉJJAS: 130-131.p.

${ }^{41}$ HIM-HL. VKF. op.cit. Eln. 1. 6740/1925. ; HIM-HL. TGY. op.cit. 3715. 138.p. ; 45 332/1924. (II. 25.) KEM.r. op.cit. 697-700.p.

${ }^{42}$ SILLAY: Katonai légi járművek nemzetközi jogi helyzete. op.cit. 123.p. ; 131-132.p.

${ }^{43}$ Szombathelyen létesített Repülőgép-vezető Iskola (REGVI) vezetésével KeNESE Waldemár légügyi aligazgatót (valójában repülő alezredes) bízták meg.

HIM-HL. VKF. op.cit. Eln. 1. 6432/1924., 6710/1925., 5396/1927. ; HIM-HL. TGY. op.cit. 2787. II. 45.p.

${ }^{44}$ VESZTÉNYI: op.cit. 215.p. ; KUNÁR — MOYS: op.cit. 43.p. ; A csendőrség és államrendőrség testületének újraszabályozása. 29.p.

${ }^{45}$ HIM-HL. SZKEB. jkv. 96/1925. 
${ }^{46}$ MoYs: Repülőtér gondnokságok, repülőtéri csendőrség a két világháború közötti időben. op.cit. 232-233.p. ; MoYs: Légiforgalmi irányításunk története. 109-111.p. ; KAISER: 59.p. + 164.p.

${ }^{47}$ HIM-HL. TGY. op.cit. 2787. II. 19.p. ; KUNÁR - MoYs: op.cit. 43.p.

${ }^{48}$ CSEPREGHY: op.cit. 147-148.p.

${ }^{49}$ Loc.cit. 150-151.p.

50 A mátyásföldi központi vámrepülötér parancsnoka SCHNEIDER Emil csendőr főhadnagy (1925. V. 1-töl százados), beosztott két tisztje pedig KovÁCs Endre és KRÓN József csendőr főhadnagy volt, valójában mindhárman katonai pilóták. Nem volt ez másként más reptérgondnokság esetében sem, Szombathelyen TóTH Elemér, Szegeden HoRváTH István csendőr százados, Miskolcon FARAGÓ Pál csendőr főhadnagy szerepelt a helyi különítmény parancsnokaként, akik szintén rejtett státuszú honvéd repülötisztek voltak.

A m. kir. csendőrség elhelyezése, 1925. 79.p.

${ }^{51}$ SILLAY: A légi közlekedés nemzetközi jogi szabályozása. op.cit. 168-169.p. ; UDVARY: 126.p.

${ }^{52}$ KAISER: op.cit. 59.p. + 164.p. ; MOYS: Légiforgalmi irányításunk története. op.cit. 109-118.p. ; A Mátyásföldi repülőtér. 83-85.p.

${ }^{53}$ UDVARY: op.cit. 129.p. + 132.p. ; TÁNCZOS: 241.p.

${ }^{54}$ A központi vámrepülötér, Mátyásföld parancsnoka SzIRTeS Ferenc cső.fhdgy. (1926. XI. 1-től százados) volt.

SZUT-1927. 24.p. ; MoYs: A Magyar Királyi Csendőrség és a rejtett Légierők kapcsolata 1924-1938. op.cit. 54-55.p. ; A magyar csendőr és a repülés. 23-24.p.

${ }^{55}$ CSANÁDI — NAGYVÁRADI - WiNKLER: op.cit. 139.p. ; A mátyásföldi repülönap. 70-71.p.

${ }^{56}$ A m. kir. csendőrség rendszeresített létszáma, 1928. 320.p.

${ }^{57}$ A LÜH vezetését 1929. XII. 16-án RÁKOsI György légügyi igazgató (vkszt. ezredes) vette át.

HIM-HL. HM. Eln. op.cit. 1. 106 400/1929. ; MoYs: A Magyar Királyi Csendőrség és a rejtett Légierők kapcsolata 19241938. op.cit. 51-57.p. + 71-74.p.

5866 000/1929. (XI. 28.) KEM.r.

${ }^{59}$ HIM-HL. VKF. op.cit. Eln. 1. 1080/1931. ; SILLAY: A légi közlekedés nemzetközi jogi szabályozása. op.cit. 172-175.p.

${ }^{60}$ CSEPREGHY: op.cit. 151-152.p. ; Magyarország légügyi hatóságai, egyesületei és légiforgalmi vállalatai. op.cit. 139.p. ; UDVARY: op.cit. 130.p. ; MoYs: A polgári repülésbe rejtett Légierők. op.cit. 79.p.

${ }^{61}$ MNL-OL. K-149. BM VII. Res. 3503/1928. ; HIM-HL. VKF. op.cit. Eln. 1. 105 447/1929. ; PUszTAI - VÁnYAI: 135.p.

${ }^{62}$ HIM-HL. TGY. op.cit. 2787. IV. 25.p. ; HÉJJAS: op.cit. 137-139.p.

${ }^{63}$ A parancsnok alá két rejtett státuszban lévő honvédtiszt és két honvéd altiszt, valamint két valódi csendőr altiszt (MÉszÁROS Péter cső.alhdgy., és BÉRCES Ferenc cső.törm., illetve 12 rejtett állományú honvéd és nyolc csendőr tartozott.

1931. VII. 15-16-án, amikor a magyar óceánrepülök, az Amerikából leszállás nélkül Magyarországra repülő ENDRESZ György és MAGYAR Sándor és a „Justice for Hungary” (Igazságot Magyarországnak) elnevezésű gép fogadására készültek a Mátyásföldi reptéren, hatalmas tömegre számítva kivezényelték a budapesti, Budapest-vidéki és a mátyásföldi rendörség 1298 rendőrét, STRAUSz László rendör-föfelügyelő vezetése alatt.

A délutáni órákban várják a „Justice for Hungary” érkezését Mátyásföldre.

${ }^{64}$ ENDRESZ György és BITTAY Gyula 1932. V. 21-ei tragikus repülöbalesete után érkezett Magyarországra az olasz „Giustizia per l'Ungheria" (Igazságot Magyarországnak) nevü gép, melyet hatalmas tömeg fogadott. Az eseményen részt vett a LÜH vezetője RÁKosi György is. A program lebonyolításáért SzIRTES FERENC cső.szds. vezette reptéri csendőr különítmény volt felelös.

Budapest népe ünnepi dísszel, ujjongó lelkesedéssel fogadta a „Giustizia per l’Ungheria” pilótáit. 1-2.p.

${ }^{65}$ HIM-HL. HM. Eln. op.cit. I. 102 633/1934. ; HIM-HL. VKF. op.cit. Eln. 1. 105 504/1933., 105 087/1934., 105 431/1935.

${ }^{66}$ PeTHÖ: op.cit. 178.p.

${ }^{67}$ MoYs: Légiforgalmi irányításunk története. op.cit. 113.p. ; RÉVÉSZ: Repülőtér az Alpokalján. A szombathelyi katonai repülötér története. $117 . \mathrm{p}$.

${ }^{68} 112$ 000/1933. (IV. 19.) KEM.r.

${ }^{69}$ HIM-HL. VKF. op.cit. Eln. 1. 5597/1928. ; Légi közlekedés. 19-20.p. ; PUNKA-SÁRHIDAI: 7.p.

70115 000/1933. (XII. 22.) KEM.r.

${ }^{71}$ HIM-HL. HM. Eln. op.cit. B. 5350/1932., 104 986/1932.

${ }^{72}$ HIM-HL. HM. Eln. op.cit. I. 452/1933.

${ }^{73}$ HÉJJAS: op.cit. 85-86.p.

${ }^{74}$ HIM-HL. VKF. op.cit. Eln. 1. 1031/1935., 1133/1935.

${ }^{75}$ Loc.cit. Eln. 1. 1224/1934. ； Légi közlekedés. op.cit. 1-5.p.

${ }^{76}$ RÁKOSI György légügyi föigazgatótól, betegsége miatt KENESE Waldemár légügyi igazgató (honv.ezds.) vette át az intézmény irányítását, akit 1936. V. 1-jén főigazgatóvá (tábornok) léptették elö.

HIM-HL. VKF. op.cit. Eln. 1. 105 318/1935. ; RÉVÉSZ: Repülötér az Alpokalján. A szombathelyi katonai repülötér története. op.cit. 120.p.

${ }^{77}$ Szemkápráztató és megdöbbentő mestermutatványok a mátyásföldi repülőnapon. ； 60000 főnyi közönség nézte végig a repülőnapot. ; A levegő hőseinek nagy parádéja.

78 1937. V. 26-án a Magyar Királyi Légügyi Hivatal (LÜH) főnöke KeNESE Waldemár főigazgató volt. HIM-HL. HM. Eln. op.cit. 14. b. 40 077/1937. 
${ }^{79}$ A Budaörsi repülőtéren felállított új reptérgondnokság CSICSERY Gyula légügyi főfelügyelö (honv.őrgy.) parancsnoksága alá került, melyhez átvezényelték Mátyásföldről a SzIRTES Ferenc vezette csendőr különítményt.

KUNÁR - MOYS: op.cit. 44.p.

${ }^{80}$ A kormányzó felavatta a budaörsi új repülőteret. ; A budaörsi repülőnap rendezősége százezer fönyi közönségre számít. Hét nemzet repülöi mutatkoznak be a budaörsi repülötér ünnepélyes megnyitásán.

812 790/1939 (III. 23.) ME.r. 447-449.p.

82 Az egyetlen megmaradt repülőtéri csendőr különítmény vezetője SzIRTES Ferenc cs.őrgy. volt.

Moys: A Magyar Királyi Csendőrség és a rejtett Légierők kapcsolata 1924-1938. op.cit. 60.

${ }^{83}$ HIM-HL. VKF. op.cit. Eln. 1. 5122/1941., 6948/1941. ; Honvédelmi határszolgálati utasitás a Magyar Királyi Honvédség, a Magyar Királyi Csendörség, a Magyar Királyi Rendörség, a Magyar Királyi Pénzügyőrség és az Allami Erdészet számára. 22.p.

${ }^{84}$ Honvédelmi határszolgálati utasitás a Magyar Királyi Honvédség, a Magyar Királyi Csendőrség, a Magyar Királyi Rendörség, a Magyar Királyi Pénzügyörség és az Állami Erdészet számára. op.cit. 15-17.p. + 29.p.

${ }^{85}$ HIM-HL. VKF. op.cit. Eln. 1. 3655/1940.

${ }^{86}$ Loc.cit. Eln. 1. 3655/1940.

${ }^{87}$ Loc.cit. Eln. 1. 4672/1939.

${ }^{88}$ Loc.cit. Eln. I. 50 445/1942.

${ }^{89}$ Loc.cit. Eln. 1. 4672/1939., 3655/1940

${ }^{90}$ A repülötéri csendőr különítmény parancsnoka SzIRTES Ferenc cső.őrgy. volt.

KAISER: op.cit. 63-64.p. ; PARÁDI: A Magyar Királyi Csendőrség szervezete. 85.p. ; VedÓ: 83.p.

9160 254/1940 (XI. 8.) KKM.r.

${ }^{92}$ A magyar csendör és a repülés. op.cit. 23-24.p.

${ }^{93}$ SZIRTES Ferenc cső.őrgy. 1940 decemberében nyugállományba vonult. Helyét a repülötéri csendőrség élén SiMONYI József cső.őrgy. (1942. IX. 30-tól cső.alez.) vette át, aki korábban a miskolci csendőr kerület 7. nyomozó alosztályának volt a parancsnoka. Az alsó fokú légügyi hatóság jogkörét gyakorló repülötéri csendör szárny végül csak Budaörsön (KAMARÁs József tths.) és Csepelen (NAGY Ferenc tths.) működött. 1941-re felállításra került a reptéri csendőrség az erdélyi régióban, Nagyváradon (BAKI Gyula tths.), Kolozsváron (SOMOGYI István tths.) és Marosvásárhelyen (PEÉRI Ferenc tths.) parancsnokságával. Légierő Parancsnokság. 145.p. ; A m. kir. csendőrség elhelyezése 1942. 110.p.

${ }^{94}$ A Központi Közlekedési Parancsnokságot KONTRA Kálmán cső.alez. vezetésével állították fel, amely 4 közlekedési szárnynyal (24 örs, 201 csendőr) rendelkezett. Ennek alárendeltségébe került a repülőtéri szárny, amelynek új parancsnoka 1943 decemberétől BocsÁNCZI Lászlő cső.szds., a szombathelyi III. csendőr kerület őrsparancsnok-képző iskolájának korábbi oktatótisztje, helyettese pedig GERENCSÉRY Mihály cső.fhdgy. a nagyváradi csendőriskola volt oktatótisztje lett.

A repülőtéri szárny új parancsnoka 1943 decemberétől BocSÁNCZI Lászlő cső.szds., a szombathelyi III. csendőr kerület őrsparancsnok-képző iskolájának korábbi oktatótisztje, helyettese pedig GERENCSÉRY Mihály cső.fhdgy. a nagyváradi csendőriskola volt oktatótisztje lett.

A m. kir. csendőrség elhelyezése, 1944. 127-129.p. ; KUnÁR-MoYs: op.cit. 42.p. ; VeSZTÉNYI: op.cit. 215.p.

${ }^{95} \mathrm{Az}$ 1. szakaszt MAGYAR József cső.főtörm., a 2. szakaszt BARANYI István cső.fötörm, a 3. szakaszt NAGY István cső.törm. vezette.

REKTOR: 204-205.p. ； A m. kir. csendőrség elhelyezése, 1944 op.cit. 127-129.p. 


\section{MONOGRÁFIÁK KISMONOGRÁFIÁK ÉS HASONLÓ JELLEGÜ KÖTETEK}

ALKÉR - AMBRÓZY

(3.;)

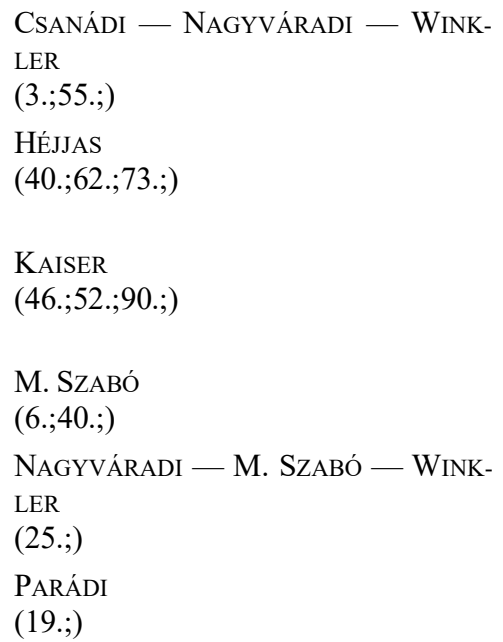

PUNKA - SÁRHIDAI

(68.;)

REKTOR

(95.;)

RÉVÉSz: A légjáró. Petróczy István, az elsö magyar katonai repülö élete.

(2.;4.;)

RÉVÉSZ: Repülötér az Alpokalján. A szombathelyi katonai repülötér története. (67.;76.;)

\section{TANULMÁNYOK}

CSEPREGHY

(18.;22.;23.;29.;48.;49.;60.;)

HADNAGY

(19.;)

KONTZ

(12.;14.;27.;)

KUNÁR - MOYS

(8.;25.;39.;44.;47.;79.;94.;)

Moys: Légiforgalmi irányításunk története.

(46.;52.;67.;)

MoYs: Repülőtér gondnokságok, repülőtéri csendőrség a két világháború közötti időben.

$(5 . ; 25 . ; 40 . ; 46 . ;)$
- Alkér Kálmán - AmBrózy Gyula (szerk.): A Magyar Békeszerződés és a becikkelyezö törvény szövege és magyarázata. Budapest, 1921, „Ordo” Törvény- és Rendelettár. 333 p. /Az Ordo törvénytára, 4./

- CSANÁdi Norbert — NAgYVÁRAdi Sándor — WinKLER László: A magyar repülés története. Budapest, 1977, Müszaki Könyvkiadó. 387.p. HU-ISBN 9631017672.

— HÉJJAs Iván: Légi jog. 1934, Első Kecskeméti Hírlapkiadó- és Nyomda Rt.

- I. köt. Magyar polgári légijog. Kecskemét, 144 p.

- II.köt. Nemzetközi Hadilégijog. Budapest, 126 p.

- KAISER Ferenc: A Magyar Királyi Csendörség története a két világháború között. Pécs, 2002, Pro Pannónia Kiadó Alapítvány. 175.p. HU-ISBN 96390 7982 0. /Pannónia Könyvek./ HU-ISSN 0237-4277.

- M. Szabó Miklós: A Magyar Királyi Honvéd Légierö 1938-1945. Budapest, 1999, Zrínyi Kiadó. 314.p. HU-ISBN 963327334 X.

- Nagyváradi Sándor — M. Szabó Miklós — WinkLer László: Fejezetek a magyar katonai repülés történetéböl. Budapest, 1986, Müszaki Kiadó. 305.p. HU-ISBN 9631066959.

— PARÁdi József: A Magyar Királyi Csendőrség. Az első magyar polgári, központositott közbiztonsági örtestület 1881-1945. Budapest, 2012, Szemere Bertalan Magyar Rendvédelem-történeti Tudományos Társaság. 281 p. HUISBN 978963084794 0. /A magyar rendvédelem-történet öröksége, 2./ HUISSN 2062-8447.

- Punka György - SÁrhidai Gyula: Magyar Sasok. A Magyar Királyi Honvéd Légierö, 1920-1945. Budapest, 2007, Zrínyi Kiadó. 203 p. HU-ISBN 9789633274231 .

- ReKTor Béla: A Magyar Királyi Csendőrség oknyomozó története. Cleveland, Ohio, USA, 1980, Árpád Könyvkiadó Vállalat. 552 p. USA-ISBN 093 4214018.

- RÉvÉSz Tamás: A légjáró. Petróczy István, az első magyar katonai repülő élete. Budapest, 2013, Zrínyi Kiadó. 320 p. HU-ISBN 9789633275825.

— RÉVÉSZ Tamás: Repülőtér az Alpokalján. A szombathelyi katonai repülőtér története. Budapest, 2009, Zrínyi. 208 p. HU-ISBN 9789630675949.

- CSEPREGHY Béla: Magyarország repülőterei és a hazai légi postaszállítás jelentősége. 142-153.p. In: Magyar Aviatikai Évkönyv, 1929. Budapest, 1929, Wodianer F. és Fiai. 257 p.

- HADNAGY Imre József: A hazai légi kutató-mentő rendszer megújításának szükségessége. Hadtudomány, XVI.évf. (2006) 1-2.sz. 111-124.p. HU-ISSN 1215-4121.p.

- Kontz Endre: A légi közlekedés rendészeti szabályai hazánkban. 192204.p. In: Magyar Aviatikai Évkönyv, 1929. Budapest, 1929, Wodianer F. és Fiai. 257 p.

— KunÁR György - MoYs Péter: Repülőtéri csendőrség a két világháború között. Magyar Repüléstörténeti Konferencia Közleményei, XXXV.évf. (2010) 35.sz. 41-48.p. HU-ISSN 1416-5287.

- Moys Péter: Légiforgalmi irányításunk története. I. rész. A Repüléstörténeti Konferencia Közleményei, XXVI.évf. (2001) 26.sz. 109-118.p. HU-ISSN 1416-5287.

- Moys Péter: Repülőtér gondnokságok, repülőtéri csendőrség a két világháború közötti időben. Magyar Szárnyak, XXXII.évf. (2004) 32.sz. 230-234.p. HU-ISSN 1416-6577. 
Moys: A Magyar Királyi Csendőrség és a rejtett Légierők kapcsolata 19241938 .

(6.;54.;57.;82.;)

MoYs: A polgári repülésbe rejtett Légierők.

(7.;11.;60.;)

PALIK

(21.;23.;29.;)

PARÁDI: A Magyar Királyi Csendőrség szervezete. (90.;)

PUSZTAI - VÁNYAI

(61.;)

Repülőtéren kívüli fel- és leszállások engedélyezésének feltételei.

(24.;)

SILlAY: A légi közlekedés nemzetközi jogi szabályozása.

(6.;10.;21.;37.;51.;59.;)

SıLLAY: Katonai légi járművek nemzetközi jogi helyzete.

(3.;42.;)

SZAKÁLY

(18.;)

VEDÓ

(90.;)

VESZTÉNYI

(8.;11.;44.;94.;)

WINKLER

(7.;9.;)

\section{CIKKEK}

60000 főnyi közönség nézte végig a repülőnapot.

(77.;)

A budaörsi repülőnap rendezősége százezer fönyi közönségre számít.

(80.;)

Budapest népe ünnepi dísszel, ujjongó lelkesedéssel fogadta a „Giustizia per l'Ungheria" pilótáit.

(64.;)

A csendőrség és államrendőrség területének újabb szabályozása.

(44.;)

A délutáni órákban várják a ,Justice for Hungary" érkezését Mátyásföldre. (63.;)
- Moys Péter: A Magyar Királyi Csendőrség és a rejtett Légierők kapcsolata 1924-1938. Magyar Repüléstörténeti Évkönyv, XXXVIII.évf. (2013) 38.sz. 49-80.p. HU-ISSN 1416-5287.

Moys Péter: A polgári repülésbe rejtett Légierők. Magyar Repüléstörténeti Évkönyv, XXXIX.évf. (2014) 39.sz. 75-106.p. HU-ISSN: 1416-5287.

- PALIK Mátyás: A repülésirányítás története. 9-37.p. In: PALIK Mátyás et al. (szerk.): A repülésirányitás alapjai. Budapest, 2018, Dialóg Campus. 205 p. HU-ISBN 9786155889431.

- PARÁDi József: A Magyar Királyi Csendőrség szervezete. Rendvédelemtörténeti Füzetek (Acta Historiae Praesidii Ordinis), XXI.évf. (2011) 24.sz. 80-90.p. HU-ISSN 1216-6774. A tanulmány korábbi változata 2009.december 3. Budapesten hangzott el, a Szemere Bertalan Magyar Rendvédelemtörténeti Tudományos Társaság által szervezett rendvédelem-történeti tudományos konferencia-sorozatnak „,Csendőrség Ausztria-Magyarországon, illetve Ausztriában és Magyarországon 1849-2005" címü XXIV. konferenciáján. A publikált tanulmány az előadás javított, bővített és átdolgozott változata.

— Pusztai János - VÁnYai László: 100 év a Tisza fölött. A szegedi repülés története. Szeged, 2015, Szegedi Közlekedési Kft. 336.p. HU-ISBN 978963 1233308.

- Repülötéren kívüli fel- és leszállások engedélyezésének feltételei. (Szerkesztőségi közlemény.) A Közlekedés, V.évf. (1933) 11.sz. 166.p.

- Sillay Aladár: A légi közlekedés nemzetközi jogi szabályozása. 163-172.p. In: Magyar Aviatikai Évkönyv, 1929. Budapest, 1929, Wodianer F. és Fiai. $257 \mathrm{p}$.

- Sillay Aladár: Katonai légi járművek nemzetközi jogi helyzete. Magyar Katonai Szemle, I.évf. (1931) 12.sz. 121-132.p.

- SzaKÁly Sándor: A Magyar Királyi Csendőrség 1919-1941. Rendvédelemtörténeti Füzetek (Acta Historiae Praesidi Ordinis), VII.évf. (1997) 8sz. 95102.p. HU-ISSN 1216-6774.

- VEDó Attila: A Magyar Királyi csendőrség közlekedési szolgálati ágának kialakulása és fejlődése. Rendvédelem-történeti Füzetek (Acta Historiae Praesidi Ordinis) XXV.évf. (2015) 47-48-49-50.sz. 81-94.p. HU-ISSN 1216-6774.

- VesZTÉNYI János: A magyar katonai repülés 1920-1945. Magyar Szárnyak, XXII.évf. (1993/1994) 22.sz. 204-224.p. HU-ISSN: 1416-6577.

- WinkLer László: A Magyar Légiforgalmi Rt. története az 1928. évi újjászervezésig. 501-520.p. In CzÉRE Béla (szerk.): A Közlekedési Múzeum Évkönyve VI. 1981-1982. Budapest, 1983, Közlekedési Dokumentációs Vállalt. 737 p. HU-ISSN 0133-4646.

— 60000 fönyi közönség nézte végig a repülőnapot. (Szerkesztőségi közlemény.) Pesti Napló, LXXXVII.évf. (1936) 136.sz. 11.p.

- A budaörsi repülőnap rendezősége százezer főnyi közönségre számít. Pesti Hírlap, LIX.évf. (1937) 124.sz. 17.p.

- Budapest népe ünnepi dísszel, ujjongó lelkesedéssel fogadta a „Giustizia per l'Ungheria” pilótáit. (Szerkesztőségi közlemény.) Pesti Hírlap, LIV.évf. (1932) 132.sz. 1-2.p.

A csendőrség és államrendőrség területének újabb szabályozása. (Szerkesztőségi közlemény.) Csendőrségi Lapok, XV.évf. (1925) 2.sz. 29.p.

A délutáni órákban várják a „Justice for Hungary” érkezését Mátyásföldre. (Szerkesztőségi közlemény.) 8 órai Újság, XVII.évf. (1931) 160.sz. 1-4.p. 
Hét nemzet repülői mutatkoznak be a budaörsi repülötér ünnepélyes megnyitásán.

(80.;)

A kormányzó felavatta a budaörsi új repülőteret.

(80.;)

A levegő hőseinek nagy parádéja.

(77.;)

A magyar csendör és a repülés.

(54.;92.;)

Magyarország légügyi hatóságai, egyesületei és légiforgalmi vállalatai. (40.;60.;)

A mátyásföldi repülőnap. (55.;)

A Mátyásföldi repülőtér.

(52.;55.;)

Szemkápráztató és megdöbbentő mestermutatványok a mátyásföldi repülőnapon.

(77.;)

TÁNCZOS

(53.;)

UDVARY

(51.;53.;60.;)

\section{ZSEBKÖNYVEK}

Légierő Parancsnokság. (93.;)

A m. kir. csendőrség elhelyezése, 1925.

(50.;)

A m. kir. csendörség elhelyezése, 1942.

(93.;)

A m. kir. csendőrség elhelyezése, 1944.

(94.;95.;)

A m. kir. csendőrség rendszeresített létszáma, 1928.

(56.;)

\section{LEVÉL-, IRAT- ÉS DOKUMENTUMTÁRI GYÜJTEMÉNYEK}

HIM-HL. HM.Eln. (1.;2.;5.;8.;9.;17.;57.;65.;70.;72.;78.;)

HIM-HL. SZKEB.

(45.;)

HIM-HL.TGY.

(1.;2.;4.;41.;43.;47.;62.;)

HIM-HL. VKF.

(4.;15.;17.;19.;41.;43.;59.;61.;65.;69.; 74;75.;76.;83.;85.;86.;87.;88.;89.;)

MNL-OL. K-149.

(61.;) (1928) 7-8.sz. 83-85.p. 136. sz. 5.p. $427 \mathrm{p}$. $455 \mathrm{p}$.
Hét nemzet repülői mutatkoznak be a budaörsi repülőtér ünnepélyes megnyitásán. (Szerkesztőségi közlemény.) Pesti Hírlap, LIX.évf. (1937) 138.sz. 12.p.

A kormányzó felavatta a budaörsi új repülöteret. (Szerkesztőségi közlemény.) Budapesti Hirlap, LVII.évf. (1937) 139.sz. 7.p.

- A levegő hőseinek nagy parádéja. (Szerkesztőségi közlemény.) Friss Újság, XXXXI.évf. (1936) 136.sz. 3.p.

A magyar csendőr és a repülés. (Szerkesztőségi közlemény.) Magyar Szárnyak, III.évf. (1940) 15.sz. 23-24.p.

Magyarország légügyi hatóságai, egyesületei és légiforgalmi vállalatai. 134-141.p. (Szerkesztöségi közlemény.) In: Magyar Aviatikai Évkönyv, 1929. Budapest, 1929, Wodianer F. és Fiai. 257 p.

— A mátyásföldi repülőnap. (Szerkesztőségi közlemény.) Aviatikai Értesítő, IV.évf. (1928) 5.sz. 71.p.

- A Mátyásföldi repülőtér. (Szerkesztőségi közlemény.) Aviatika, III.évf.

- Szemkápráztató és megdöbbentő mestermutatványok a mátyásföldi repülőnapon. (Szerkesztőségi közlemény.) Budapesti Hirlap, LVI. évf. (1936)

TÁnczos László: A nemzetközi légi forgalom. 230-243.p. In: Magyar Aviatikai Évkönyv, 1929. Budapest, 1929, Wodianer F. és Fiai. 257 p.

- UdVARY Jenő: A magyar aviatika helyzete. 122-134.p. In: Magyar Aviatikai Évkönyv, 1929. Budapest, 1929, Wodianer F. és Fiai. 257 p.

— Légierő Parancsnokság. 145.p. In BARCZA Pál - HAJÓs László - KoMLÓsY Ferenc (szerk.): Rendörségi Zsebkönyv. Budapesti útmutató és címtár. Budapest, 1942, Pallas Irodalmi és Nyomdai Részvénytársaság. 460 p.

A m. kir. csendőrség elhelyezése, 1925. 76-134.p. In PINCZÉs Zoltán (szerk.): A Magyar Királyi Csendörség Zsebkönyve 1925. Budapest, XXXIII.évf., 1925, Csendőrségi Lapok. 376 p.

A m. kir. csendőrség elhelyezése, 1942. 101-240.p. A Magyar Királyi Csendörség Zsebkönyve 1942. Budapest, L.évf., 1942, Csendőrségi Lapok.

A m. kir. csendőrség elhelyezése, 1944. 119-264.p. A Magyar Királyi Csendörség Zsebkönyve 1944. Budapest, LII.évf., 1944, Csendőrségi Lapok.

A m. kir. csendőrség rendszeresített létszáma, 1928. 314-335.p. In PINCZÉsZoltán (szerk.): A Magyar Királyi Csendörség Zsebkönyve 1928. Budapest, XXXVI.évf., 1928, Csendőrségi Lapok. 372 p.

- HIM (Hadtörténeti Intézet és Múzeum), HL (Hadtörténelmi Levéltára), HM.Eln. (Honvédelmi Minisztérium elnökségi iratok).

- HIM (Hadtörténeti Intézet és Múzeum), HL (Hadtörténelmi Levéltára), SZKEB (Szövetségközi Katonai Ellenőrző Bizottság iratai).

- HIM (Hadtörténeti Intézet és Múzeum), HL (Hadtörténelmi Levéltára), TGY (Tanulmánygyüjtemény iratai).

- (HIM) Hadtörténeti Intézet és Múzeum, (HL) Hadtörténelmi Levéltára, (VKF) Vezérkari Főnökség iratai.

- (MNL) Magyar Nemzeti Levéltár, (OL) Országos Levéltár, (K-149) Belügyminisztérium rezervált iratai. 


\section{JOGSZABÁLYGYÜJTEMÉNYEK}

Légi közlekedés. (69.;75.;)

РETHÖ

(12.;16.;66.;)

\section{SZABÁLYZATOK}

Honvédelmi határszolgálati utasitás a Magyar Királyi Honvédség, a Magyar Királyi Csendörség, a Magyar Királyi Rendörség, a Magyar Királyi Pénzügyörség és az Állami Erdészet számára. (83.;84.;)

SZUT-1927

(54.;)

\section{JOGSZABÁLYOK}

1922/XVII.tc.

10 270/1922. (XII. 14.) ME.r. (12.;13.;14.;16.;30.;)

45 340/1923. (IV. 28.) KEM.r. (28.;)

46 402/1923. (III. 9.) KEM.r. (35.;)

1 630/1924. (II. 22.) ME.r. (31.;)

45 179/1924. (IV. 5.) KEM.r. (38.;39.;)

45 264/1924. (III. 8.) KEM.r. (20.;31.;32.;33.;34.;36.;)

45 332/1924. (II. 25.) KEM.r. (26.;41.;)

66 000/1929. (XI. 28.) KEM.r. (58.;)

112 000/1933. (IV. 19.) KEM.r. (68.;)

115 000/1933. (XII. 22.) KEM.r. (70.;)

2 790/1939. (III. 23.) ME.r.

(81.;)

60 254/1940 (XI. 8.) KKM.r. (91.;)
— Légi közlekedés. (Rendeletek.) Budapest, 1936, KEM. 40 p.

— Pethö Ádám (szerk.): A légi közlekedés jogszabályai. Budapest, 1943, Urbányi Ny. 274.p.

- Honvédelmi határszolgálati utasitás a Magyar Királyi Honvédség, a Magyar Királyi Csendörség, a Magyar Királyi Rendörség, a Magyar Királyi Pénzügyőrség és az Állami Erdészet számára. Budapest, 1940, Magyar Királyi Honvédelmi Minisztérium. 33 p.

- Szervezeti és szolgálati utasitás a Magyar Királyi Csendörség számára. Budapest, 1927, Pallas. 411 p.

- 1922/XVII.tc. az 1922/23. költségvetési év első hat hónapjában viselendő közterhekről és fedezendő állami kiadásokról.

- 10 270/1922. (XII. 14.) ME.r. a légi közlekedésröl. Magyarországi Rendeletek Tára, LVI.évf. (1923) 1.sz. 192-203.p.

- 45 540/1923. (IV. 28.) KEM.r. a Magyarországon lajstromozott légi jármüveken alkalmazandó jelzésekről. Budapesti Közlöny, LVII.évf. (1923) 100.sz. 11.p.

— 46 402/1923. (III. 9.) KEM.r. a légi járóművek bejelentéséről, nyilvántartásáról, alkalmasságuk megállapításáról, lajstromozásukról, kísérő irataikról és a kapcsolatos rendelkezésekről. Magyarországi Rendeletek Tára, LXVIII.évf. (1924) I.füzet. 720-739.p.

- $\quad 1630 / 1924$. (II. 22.) ME.r. a légi közlekedésről szóló rendelet módosításáról és kiegészítéséröl. Magyarországi Rendeletek Tára, LVIII. évf. (1924) I.füzet. 30-33.p.

- 45 179/1924. (IV. 5.) KEM.r. a m. kir. Légügyi Hivatal felállításáról szervezetének és hatáskörének megállapításáról. Magyarországi rendeletek tára, LVIII.évf. (1924) I.füzet. 745-749.p.

- $\quad 45$ 264/1924. (III. 8.) KEM.r. a repülőtérre, léghajókikötőre és vízi repülöállomásra fennálló és kapcsolatos rendelkezések végrehajtásáról (repülőtérrendtartás). Magyarországi Rendeletek Tára, LVIII. évf. (1925) I.füzet. 709-720.p.

- 45 332/1924. (II. 25.) KEM.r. a külföldi légi járóművek közlekedéséröl. Magyarországi Rendeletek Tára, LVIII. évf. (1925) I.füzet. 697-700.p.

- 66 000/1929. (XI. 28.) KEM.r. a légi járóművek bejelentése, nyilvántartása, alkalmasságuk megállapítása, lajstromozásuk, kísérő irataik és a kapcsolatos rendelkezések tárgyában kiadott 46.402/1923.K.M. rendelet módosításáról. Magyarországi Rendeletek Tára, LXIII.évf. (1929) I.füzet. 1752-1758.p.

- $\quad 112$ 000/1933. (IV. 19.) KEM.r. a Magyarországon lajstromozott légijárómüveken alkalmazásra kerülő jelzésekről. Magyarországi Rendeletek Tára, LXVII.évf. (1933) I.füzet. 1304-1306.p.

- $\quad 115$ 000/1933. (XII. 22.) KEM.r. a külföldi légijáróművek közlekedéséről. Magyarországi Rendeletek Tára, LXVII.évf. (1933) I.füzet. 3069-3077.p.

— 2 2790/1939. (III. 23.) ME.r. a légiközlekedési ügyek intézésének szabályozásáról. Magyarországi rendeletek tára, LXX.évf. (1938) I.kötet. 447-449.p.

- 60 254/1940 (XI. 8.) KKM.r. a repülőtérre, légihajókikötőre és vízi repülöállomásra fennálló és a kapcsolatos rendelkezések végrehajtása tárgyában (repülőtérrendtartás) kiadott 45.264/1924. K. M. rendelet módosításáról és kiegészítéséröl.

Magyarországi Rendeletek Tára, LXXI.évf. (1940) I-II.füzet. 3830-3832.p. 


\section{Mellékletek jegyzéke:}

I.sz. melléklet

Magyar repülés a Kereskedelemügyi Minisztérium felügyeletével, a Magyar Aeroforgalmi Részvénytársaság (MAEFORT) gondozásával 1920. II. 11. - 1921. XII. 8.

II.sz. melléklet

Reptérgondnokságok - repülötéri csendőr különítmények, légikapuk - tiltott zónák, egyesületek.

III.sz. melléklet

A magyar légicsendörség területi elhelyezkedése.

IV.sz. melléklet

A Magyar Királyi Csendörség repülötéri szárnyának diszlokációja.

V.sz. melléklet

A magyar légicsendörség szervezeti felépitése.

VI.sz. melléklet

A Magyar Királyi Csendörség repülőtéri szárnyának szervezeti felépitése. 


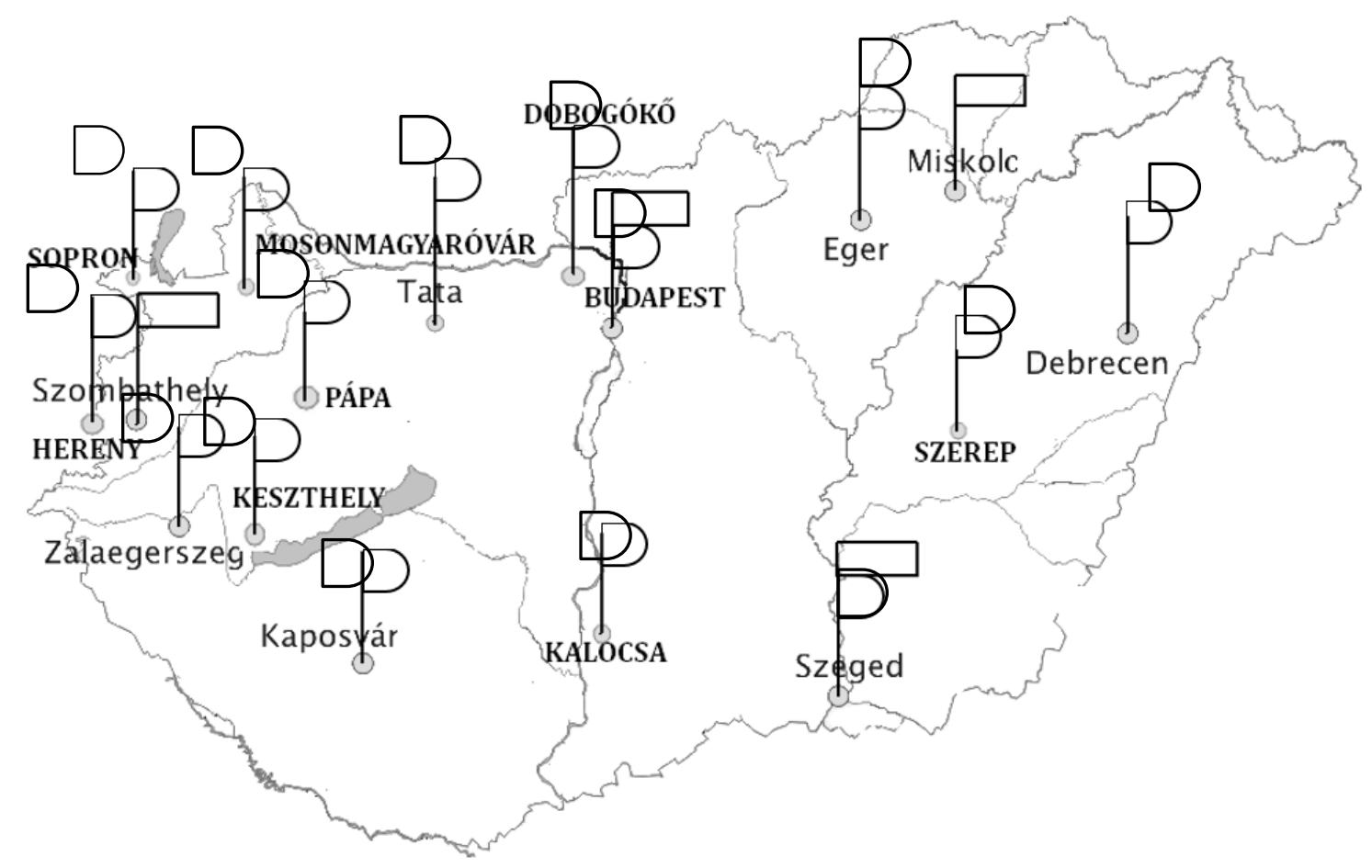

Jelmagyarázat:

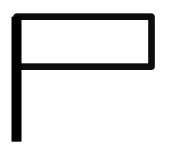

= közforgalmi repülőtér

(Budapest, Miskolc, Szeged, Szombathely)
= a repülés számára adatokat szolgáltató meteorológiai állomás.

(Budapest, Dobogokő, Eger, Szerep, Debrecen, Szeged, Kalocsa, Kaposvár, Keszthely, Zalaegerszeg, Pápa, Herény, Sopron, Mosonmagyaróvár, Tata)

Megjegyzés:

- 1921. V. 5. a Nagykövetek Tanácsa megtiltotta a legyözöttek számára a motoros gépek gyártását és beszerzését.

- 1921. VI. 26. - 1922. I. 26. teljes repülési tilalmat rendeltek el a magyar gépek számára.

- 1921. VII. 26. - 1921. XI. 7. a Szövetségközi Katonai Ellenőrző Bizottság Légügyi Ellenőrző Bizottsága az országot járva a megtalált magyar repülőgépeket szétromboltatta.

- 1921. XI. 7. a magyar kormány — a további pusztítást megakadályozandó — a hangárok és egyéb repülés kiszolgáló létesítmények használati jogát a repülési tilalom lejártáig átadta a győztes hatalmaknak.

- 1921. I. 26. a lejáró repülési és repülőgép építési tilalmat a Nagykövetek Tanácsa az év végéig meghosszabbította.

- 1921. XII. 8. a MAEFORT a Szövetségközi Katonai Ellenőrző Bizottság müködését megszüntette. 
Reptérgondnokságok - repülötéri csendör különítmények, légikapuk - tiltott zónák, egyesületek.

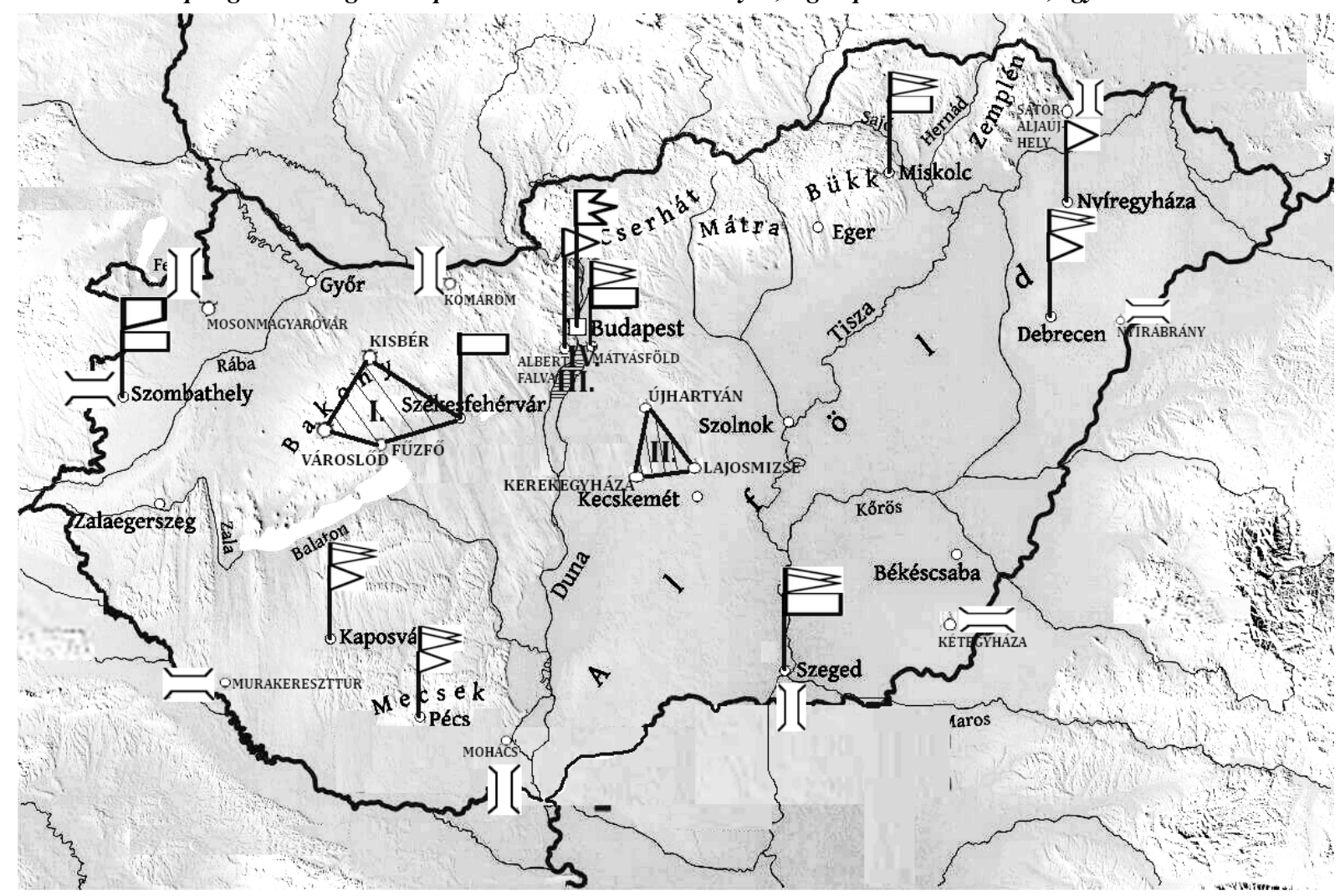

Jelmagyarázat:

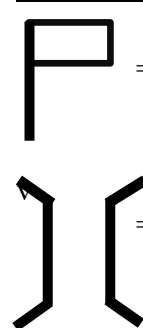

= repülőtéri csendőr különítmények (Mátyásföld, Miskolc, Szeged, Székesfehérvár [1924-töl csak belföldi gépeknek], Szombathely)

\section{$=$ légikapuk}

(Sátoraljaújhely, Nyírábrány, Kétegyháza, Szeged, Mohács, Murakereszttúr, Szombathely, Mosonmagyaróvár, Komárom)

8

$=$ sportrepülö egyesületek

(Mátyásföld, Szeged, Pécs, Debrecen, Miskolc, Kaposvár)

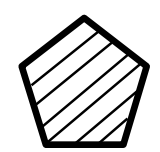

= tilalmi övezet

I. Kisbér, Székesfehérvár, Füzfö, Városlöd ; II. Újhartyán, Lajosmizse, Kerekegyháza Peszérpuszta; III. Észak-Csepel ; IV. Budafok

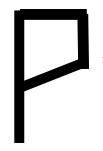

= pilótaiskola

(Szombathely)

= Magyar Királyi Légügyi Hivatal

(Budapest)

Megjegyzés:

- 1922. III. 1. reptérgondnokságok felállítása, feladataikat a reptéri csendőr különítmények végzik.

- 1922. IX. 14. megszünt a repülési tilalom.

- 1922. XI. 17. megszünt Magyarország közvetlen légügyi ellenőrzése.

- 1922. XI. 19. megalakult a Magyar Légiforgalmi Rt. (MLRT).

- 1923. I. 1. Magyarország légügyi szuverenitása helyreállt.

- 1923. IV. 26. az antant hatalmakkal 1921. XI. 7-én kötött szerződés helyébe a kormány új szabályozást hozott létre.

- 1924. IV. 10. felállították a Magyar Királyi Légügyi Hivatalt (LÜH).

- 1926. a „9-es szabályt” a párizsi légügyi egyezmény váltotta fel.

- 1927. III. 31. megszünt a Szövetségközi Katonai Ellenőrző Bizottság (SZKEB) helyszíni ellenőrzése.

- 1933. IV. 14. tilalmi övezetek kialakítása.

- 1939. III. 24. kormányrendeletben választották szét a katonai és a polgári repülést. 


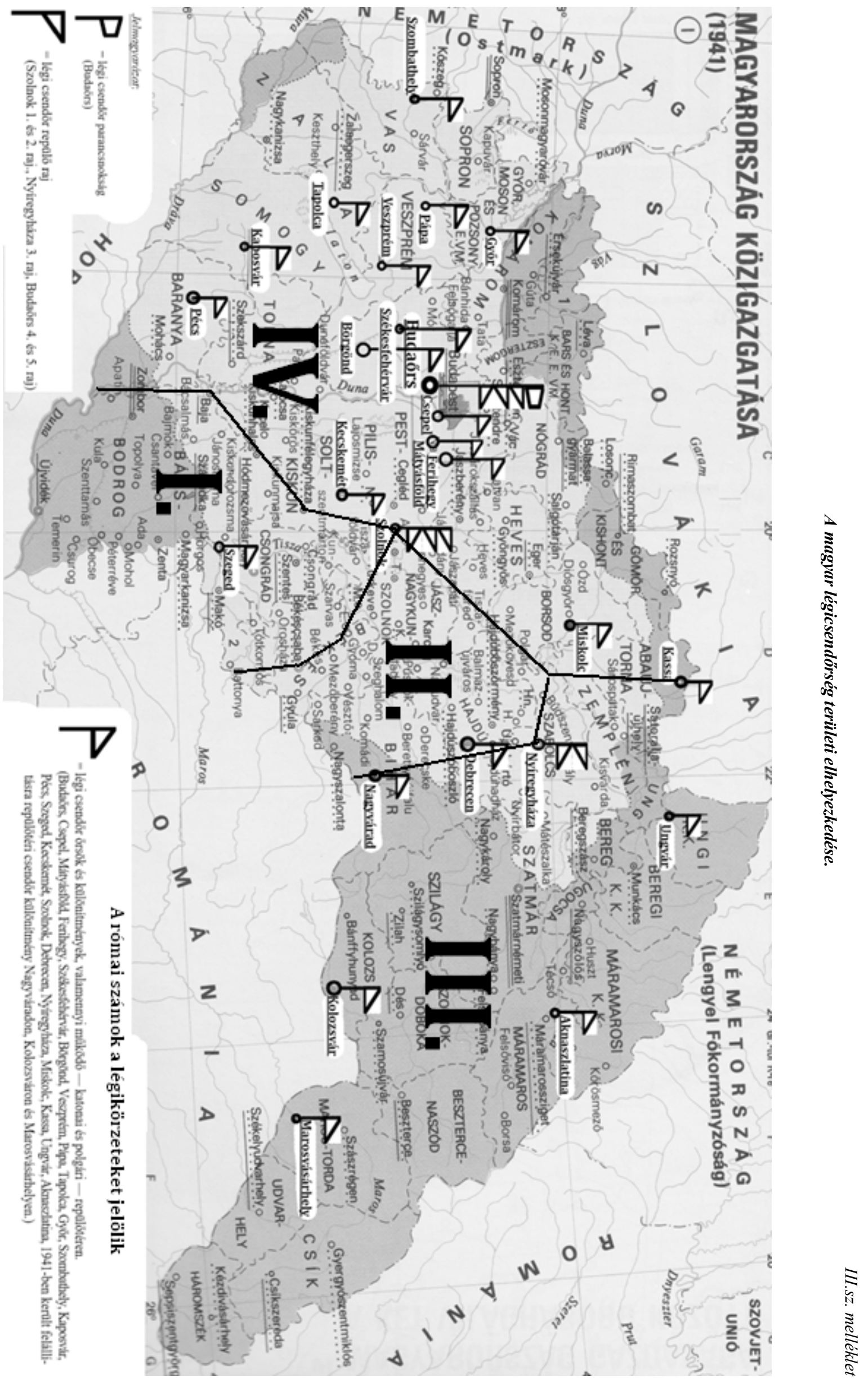




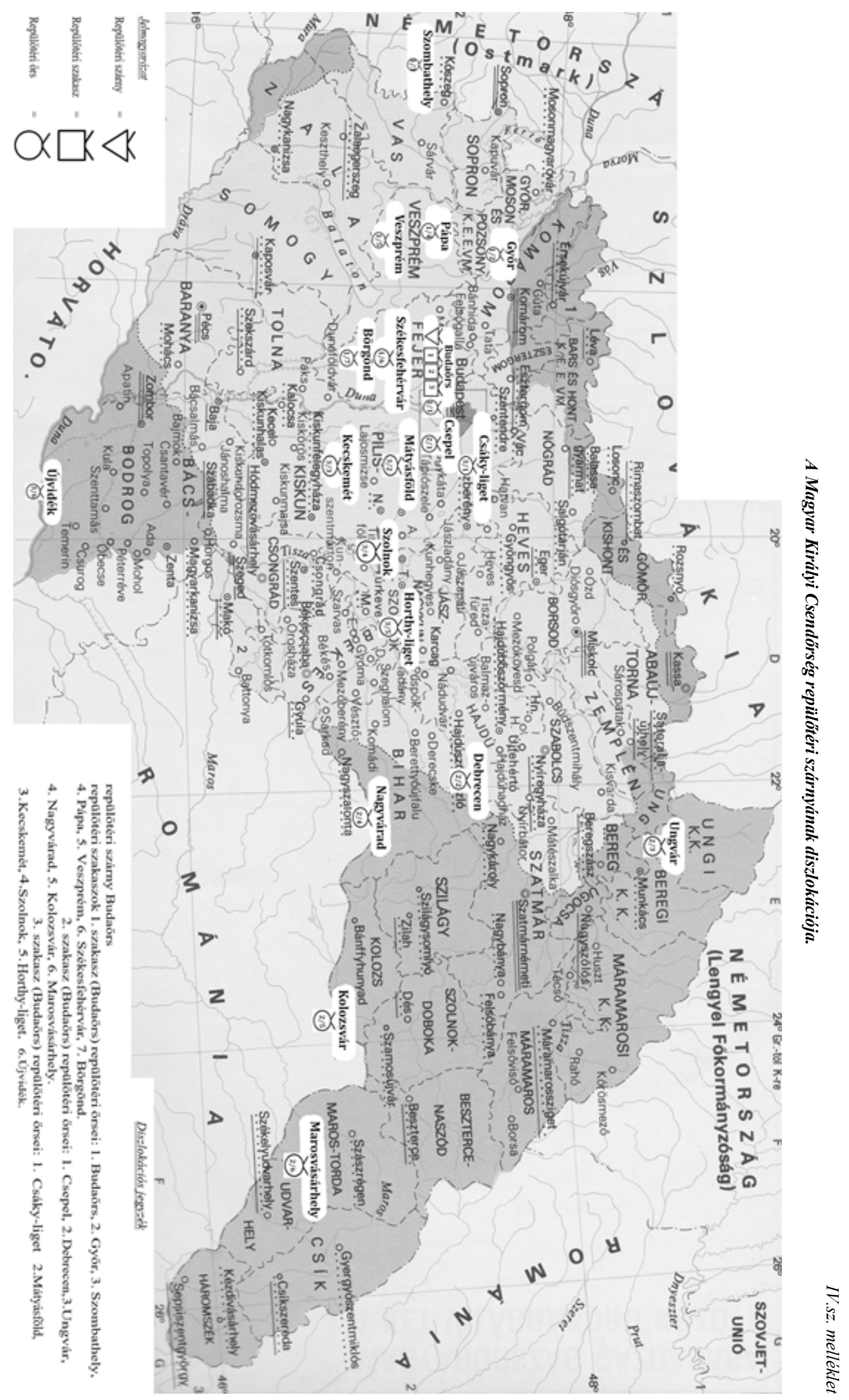




\section{A magyar légicsendőrség szervezeti felépittése.}

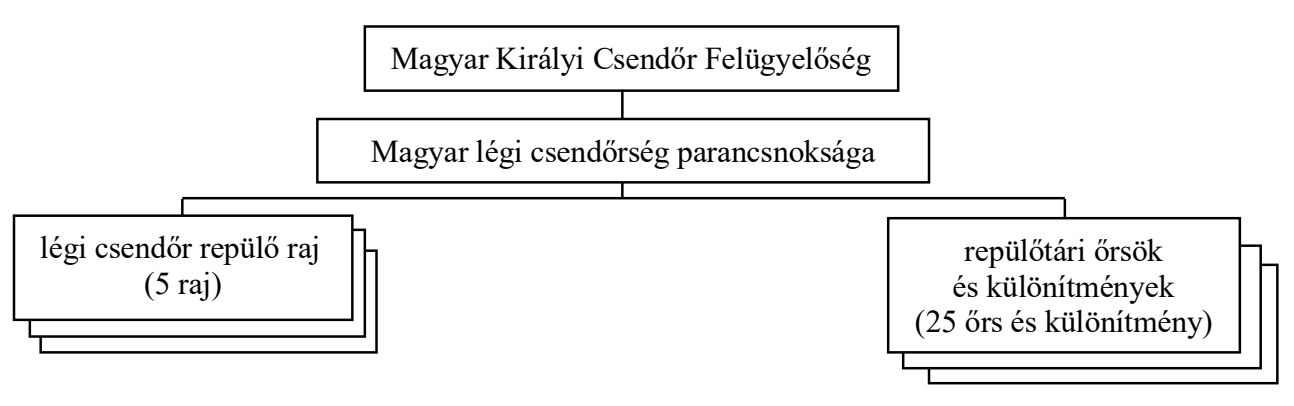

A Magyar Királyi Csendőrség repülōtéri szárnyának szervezeti felépítése.

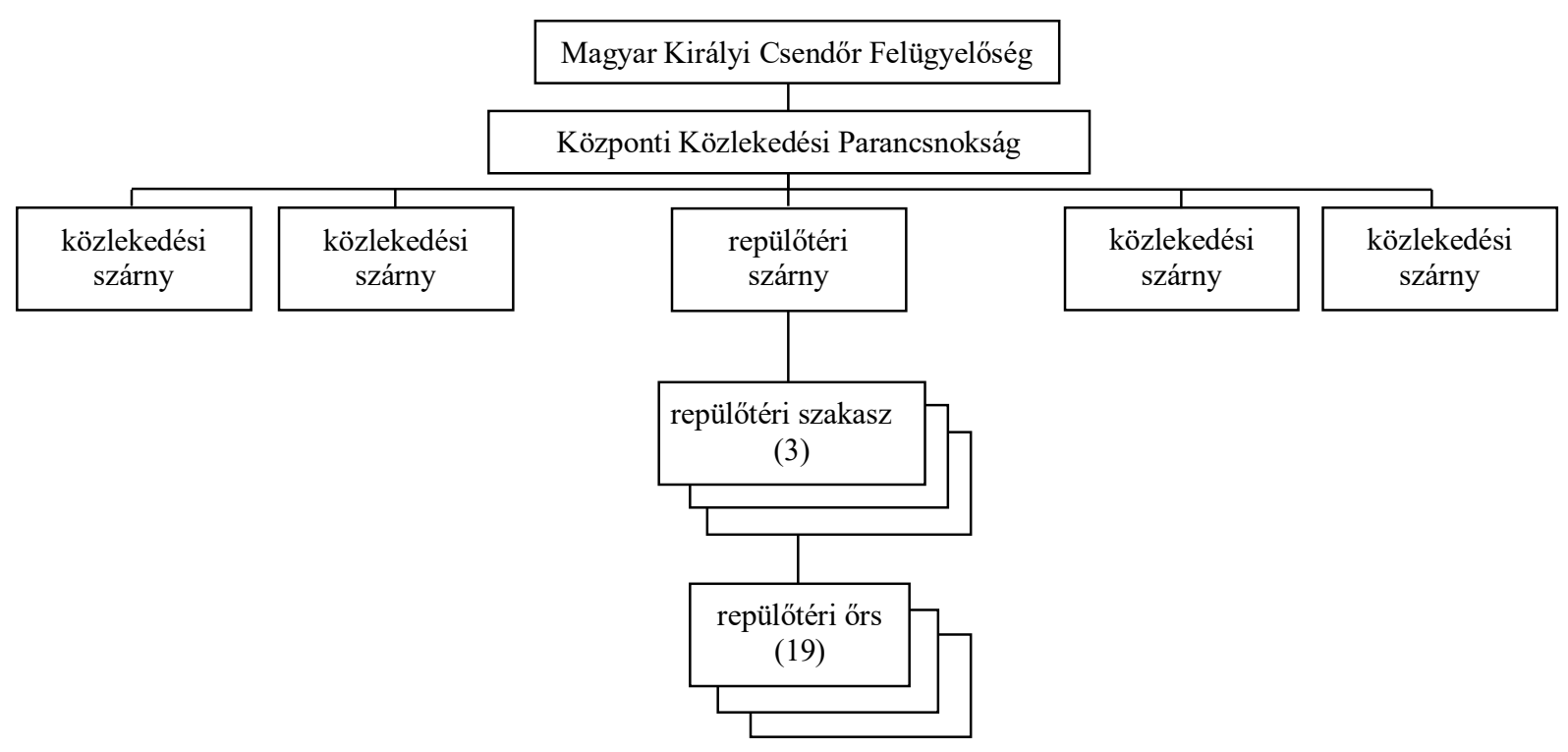

